\title{
The mollusks' periodic table: Elemental analysis reveals distinct mineralization patterns in radular teeth
}

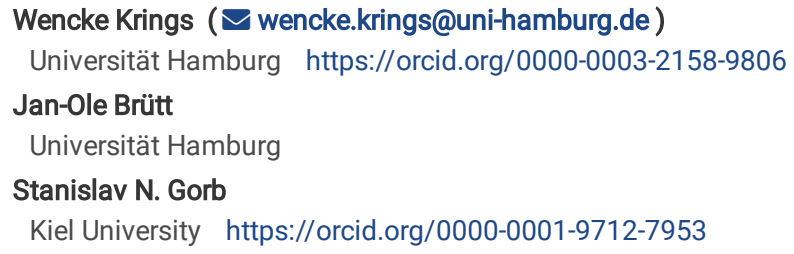

Article

Keywords: elemental composition, material properties, mollusca, feeding, biomineralization

Posted Date: March 1st, 2022

DOI: https://doi.org/10.21203/rs.3.rs-1327743/v2

License: () (i) This work is licensed under a Creative Commons Attribution 4.0 International License. Read Full License 


\section{Abstract}

The molluscan phylum is the second specious animal group inhabiting various habitats and feeding on a variety of food sources. The latter is enabled by the radula, a small chitinous membrane with embedded teeth, one important molluscan autapomorphy. Between species, radulae can vary in their morphology, mechanical, and chemical properties. With regard to radular chemical composition, some taxa (Polyplacophora and Patellogastropoda) were studied extensively in the past decades, due to their specificity to incorporate high proportions of iron, calcium, and silicon. There is, however, a huge lack of knowledge about radular chemical composition in other molluscan taxa. The work presented here aims at shedding light on the radular chemistry by performing energy-dispersive X-ray spectroscopy (EDX) analyses on overall 24 molluscan species, thereof two Polyplacophora, two Cephalopoda, and 20 Gastropoda, which was never done before in such a comprehensiveness. The elements, which are not part of chitin, and their proportions were documented for overall 1448 individual, mature teeth and hypotheses about potential biomineralizations types were proposed. The here presented work additionally comprises a detailed record on past studies about the chemical composition of molluscan teeth, which is an important basis for further investigation of the radular chemistry. The found disparity in elements detected, in their distribution and proportions highlights the diversity of evolutionary solutions, as it depicts multiple biomineralization types present within Mollusca.

\section{Introduction}

The radula is the molluscan autapomorphy for food gathering and processing. Overall, its general shape reflects the deep molluscan phylogeny, whereas the fine morphology and chemical composition seem to be usually species-specific, serving as taxonomic character. All parameters are also, however, considered as adaptations to different ingesta types (food type, minerals, the substrate where the food is collected from, etc.) related to the ecological niche of particular species.

In most molluscan classes, the radula consists of a membrane with rows of embedded teeth, which form, together with underlain odontophoral cartilages, surrounding muscles, alary processus, and in some taxa also the jaw, the feeding apparatus, i.e. the buccal mass. The radula itself is continuously regrown by secretion of over- and underlain epithelia situated in the 'radular sac', before it is maturated in the 'maturation zone' and finally enters the 'working zone', where teeth interact with the ingesta [e.g. 1-3].

Past studies related the radular morphology and general buccal mass anatomy with the ingesta preferred [e.g. 4-13], supplemented by phenotypic plasticity studies addressing the morphological answers to shifts in the diet [e.g. 14-18]. However, the radular tooth shape is not always a good indicator for trophic specializations [19], since morphology seems to be more phylogenetically fixated and rather less adaptive in some cases [12]. Additionally, experimental approaches revealed that not all teeth necessarily interact with the ingesta, but still contribute to the overall radular function by e.g. reinforcing the spanned radula $[20,21]$, which indicates that tooth function and the identification of potential trophic adaptations is more complex than it has been thought before.

The mechanical properties (e.g. stiffness and hardness) of the radular teeth material can be considered as adaptive to certain ingesta types. This is well investigated for the dominant lateral teeth of Polyplacophora and patelliform gastropods, which are of strong stiffness and hardness being adaptations to feeding on algae covering rocks [22-28]. For these taxa, the mechanical parameters have their origin in the architecture of the organic components (matrix of alpha chitin with associated proteins) as e.g. fiber orientation or density, the distinct folding or bonding conditions of the chitin, and the amount/distribution of the inorganic components (iron, silicon, and calcium) [e.g. 23, 25, 27-32; for reviews see 33-36].

This direct relationship between ingesta and tooth mechanical properties was recently also described for closely related paludomid gastropods from Lake Tanganyika; here species feed either on algae covering sand, mud, rock, or multiple surfaces [12, 37-40]. The origins of the differences in hardness and stiffness remained, however, enigmatic, as radular teeth are completely understudied with regard to their structural organization and chemical composition outside the polyplacophoran or limpet realm. Only very few past studies focused on the radular composition in non-patelliform gastropods [e.g. 41-43], cephalopods [43], or scaphopods [43-45].

We thus aim here on shedding some light on the chemical composition of radular teeth. We performed elemental analyses using energy disperse $\mathrm{x}$-ray spectroscopy (EDX), overall on 1448 mature teeth of 24 species, thereof two Polyplacophora, two Cephalopoda, and 20 Gastropoda species. For the gastropods, we have chosen representative taxa from the Vetigastropoda, Neritimorpha, Heterobranchia, Caenogastropoda, and one Patellogastropoda for comparison. For the Caenogastropoda, we included six paludomid species from Lake Tanganyika, which were previously studied extensively with regard to the radular tooth mechanical properties, because one goal was the determination of the origin of heterogeneities. The elements incorporated in the mature teeth were identified, documented, and compared between the species studied. The aim of this project is the identification of similarities and differences in tooth mineralization between the molluscan taxa, which was never done before for such an elevated quantity of taxa. The results are compared and interpreted against the background of previous studies on the chemical composition of radular teeth and functional adaptations of different radulae.

\section{Results}

Radular morphology and types

Overall, the here analyzed radulae are highly distinct in morphology, size, and quantity of tooth rows (see Table 1 and Supplementary Figures 1-24 for each species). However, these differences are rather interspecific, as the selected specimens, which were of similar body size for each species, show only little intraspecific variability in the radular parameters studied here. 
Based on the arrangement and quantity of certain tooth shapes, the radulae of the studied species could be assigned to the following published radular type categories (see Table 1): those of the Polyplacophora and Patellogastropoda to the docoglossan, those of the Cephalopoda to the homodont, those of the Vetigastropoda and Neritimorpha to the rhipidoglossan (special type 'neritinomorph' for Vittina turrita), those of the Caenogastropoda to the taenioglossan or stenoglossan, and those of the Heterobranchia Doris pseudoargus and Cornu aspersum to the isodont type. Radulae of Onchidoris bilamellata, Aeolidia papillosa, and Polycera papillosa could not be assigned to existing categories due to their diverging morphologies. The categories usually reflect phylogeny, except for the docoglossan type, which was detected in Polyplacophora and Gastropoda (Patellogastropoda). Within Heterobranchia, specifically Nudibranchia (O. bilamellata, A. papillosa, P. quadrilineata, D. pseudoargus), we detect a rather large diversity of radular shapes and thus different types. In addition, radular formulae, based on the quantity and arrangement of teeth with a specific shape, were determined. These do not consistently reflect phylogeny, except for Polyplacophora, Cephalopoda, and each of the two large Caenogastropoda groups (Buccinoidea and Paludomidae), since selected radulae are rather diverging in their interspecific morphology.

Histioteuthis spec. possesses the shortest radula ( $<1 \mathrm{~mm})$, Patella vulgata the longest one $(37 \mathrm{~mm})$. Faunus ater, Haliotis tuberculata, V. turrita, and Littorina littorea show radulae that are of 10-23 mm length, all other species of 1.4-10 mm. Areas of radulae in Buccinum undatum, V. turrita, $C$. aspersum, and $P$. vulgata are rather large $\left(14-35 \mathrm{~mm}^{2}\right)$. The largest one was detected for $H$. tuberculata $\left(59 \mathrm{~mm}^{2}\right)$ and the smallest for $H$. spec. $\left(0.39 \mathrm{~mm}{ }^{2}\right)$. Most species have less than 100 tooth rows, with $A$. papillosa possessing the smallest quantity (9 rows). The radulae of Rochia conus, Lavigeria nassa, H. tuberculata, Spekia zonata, F. ater, C. aspersum, Reymondia horei, and $P$. vulgata contain 100-200 rows. V. turrita's radula possesses $149-151$ rows, whereas $L$. littorea's one has the highest number of rows (280-281). Length, area, and tooth row number do not seem to relate to the phylogeny as closer related species (e.g. the Paludomidae: L. nassa, L. grandis, R. horei, S. zonata, and C. johstoni) show large differences in these parameters.

Ingesta

Overall, the preferred ingesta types (see Table 1) vary greatly within classes, especially within Vetigastropoda, Caenogastropoda, and Heterobranchia, and convergent adaptations to similar trophic categories are present. The two studied Polyplacophora species (Acanthochitona fascicularis and Lepidochitona cinerea), the Patellogastropoda Patella vulgata, the Vetigastropoda Rochia conus, the Caenogastropoda Lavigeria grandis, L. nassa, Reymondia horei, and Spekia zonata can be regarded as solid ingesta feeders. Neritimorpha Vittina turrita and Caenogastropoda Littorina littorea seem to forage on solid, but also medium hardness ingesta, the Vetigastropoda Haliotis tuberculata and the Heterobranchia Onchidoris bilamellata, Polycera quadrilineata, and Doris pseudoargus on ingesta of medium stiffness and hardness. The Caenogastropoda Cleopatra johnstoni and the Heterobranchia Aeolidia papillosa were the only species foraging on softer ingesta. The Cephalopoda Histioteuthis spec. and Loligo vulgaris, the Caenogastropoda Paramelania damoni, Faunus ater, Anentome helena, and Buccinum undatum, as well as the Heterobranchia Cornu aspersum seem to forage on the widest range of food types (soft to solid).

Elements detected

Overall, the presence of many elements is rather puzzling and does not follow, in each case, the phylogeny (see Figures 1-2, Supplementary Figures 1-27, Supplementary Table 1): S was detected in the radula of each studied species. $\mathrm{Mg}, \mathrm{Ca}, \mathrm{Na}$, and $\mathrm{P}$ in most, but in Cornu aspersum no $\mathrm{Mg}$, $\mathrm{Na}$, and $\mathrm{P}$ and in Cleopatra johnstoni no Ca was found. Cl was determined for radulae of Acanthochitona fascicularis, both Cephalopoda, Vittina turrita, all Caenogastropoda, Onchidoris bilamellata, and Aeolidia papillosa. F was detected in A. fascicularis, Patella vulgata, both Vetigastropoda, Littorina littorea, O. bilamellata, and Doris pseudoargus. Si was found in Lepidochitona cinerea, both Cephalopoda, $P$. vulgata, both Vetigastropoda, $V$. turrita, all Caenogastropoda except $C$. johnstoni and Buccinum undatum, and in Cornu aspersum. Cu was determined for radulae of both Cephalopod species and Reymondia horei. $\mathrm{K}$ was found in both Polyplacophora, P. vulgata, Paramelania damoni, C. johnstoni, R. horei, Paludomus siamensis, L. littorea, and O. bilamellata.

\section{Elemental proportions}

Summarizing all radulae studied, we detect that Fe is present in the highest proportions (mean \pm SD in atomic \%; $9.14 \pm 10.41$ ), followed by Si (1.97 \pm 5.76$)$, Ca (1.72 \pm 1.95$), \mathrm{P}(1.16 \pm 1.50), \mathrm{F}(0.48 \pm 0.60), \mathrm{Na}(0.39 \pm 0.51), \mathrm{Mg}(0.36 \pm 0.48), \mathrm{S}(0.35 \pm 0.44), \mathrm{Cl}(0.29 \pm 0.32), \mathrm{Cu}(0.24 \pm 0.16)$, and finally K (0.19 \pm 0.30$)$. Of the 1448 areas studied, 1220 of them contained Ca, 974 P, $961 \mathrm{Mg}, 831$ S, $638 \mathrm{Cl}, 619 \mathrm{Na}, 365 \mathrm{Si}, 336 \mathrm{~F}, 182 \mathrm{Fe}, 146 \mathrm{Cu}$, and K was detected in least areas (100).

Overall, the highest content of all analyzed elements (sum, in atomic \%, of the means of F, Na, Mg, Si, P, S, Cl, K, Ca, Fe, and Cu) was detected for the studied Patellogastropoda (Patella vulgata, $40.95 \%$ ). This is followed by the Polyplacophora (for both species, $24.01 \%$; for Acanthochitona fascicularis, $28.04 \%$, and Lepidochitona cinerea, $21.75 \%$ ), Heterobranchia (for all species, 11.38 \%; for Onchidoris bilamellata, 19.59 \%, Doris pseudoargus, 8.76 \%, Aeolidia papillosa, $7.40 \%$, Polycera quadrilineata, $5.89 \%$, and Cornu aspersum, $3.28 \%$ ), Caenogastropoda (for all species, 4.40 \%; for Anentome helena, 6.27 \%, Buccinum undatum, 5.59 \%, Littorina littorea, 4.44 \%, Spekia zonata, 3.62 \%, Reymondia horei, 3.32 \%, Lavigeria grandis, 3.12 \%, Lavigeria nassa, $2.08 \%$, Paramelania damoni and Faunus ater, 1.37 \%, Paludomus siamensis, 1.34 \%, and Cleopatra johnstoni, $1.16 \%$ ), Cephalopoda (for all species, $3.15 \%$; for Histioteuthis spec., $3.48 \%$, and Loligo vulgaris, $2.83 \%$ ), Vetigastropoda (for all species, $2.72 \%$; for Haliotis tuberculata, $2.49 \%$, and Rochia conus, $2.32 \%$ ), and finally the Neritimorpha (Vittina turrita, $2.69 \%)$. 
Overall, we detect that multiple composition- and biomineralization types are present within each individual species and also within individual teeth (see Figure 2). Within Polyplacophora and Patellogastropoda we detected strong indications for the presence of the composition type I (containing Fe), II (Mg, Ca), III (Ca, P, Cl, F), IV (Si), OB (Na, S, K). In Cephalopoda, the types II, III, IV, V (Cu), and OB occur. In Vetigastropoda and Neritimorpha, the types II, III, IV, and OB were detected, in Vittina turrita - additionally the type I. In Caenogastropoda and Heterobranchia, the radular composition greatly varies between taxa. Overall, in Caenogastropoda, all composition types were found. However, in each species, the types II, III, and OB were always present, whereas Fe was only determined in Reymondia horei and Littorina littorea, $\mathrm{Cu}$ - in R. horei, and K - in Paramelania damoni, Cleopatra johnstoni, R. horei, Faunus ater, and L. littorea. C. johnstoni is the only species that seems to lack Ca. In Heterobranchia, the types II and OB were found in each species. The type III (apatite) is present in Onchidoris bilamellata, Aeolidia papillosa, Polycera quadrilineata, and Doris pseudoargus, but not in Cornu aspersum, as $\mathrm{P}, \mathrm{Cl}$, and $\mathrm{F}$ were not determined in this species. Si was only detected in $C$. aspersum and $\mathrm{K}$ in $\mathrm{O}$. bilamellata.

Ingesta vs. radular morphology and elemental proportions

Morphology. The longest radulae were detected in species foraging on medium to solid ingesta, followed by solid-, medium-, soft-to-solid-, and finally softfeeders with the shortest radulae (see Table 2 and Supplementary Figures 28-30). The largest radular area was calculated for medium-, medium-to-solid-, soft-to-solid-, solid-, and finally for the soft-feeders with the smallest area. Species foraging on medium-to-solid ingesta possess the highest quantity of tooth rows, followed by solid-, soft-to-solid-, medium-, and finally with the least quantity of tooth rows the soft-feeders.

All elements: In general, we detect that radulae of species foraging on solid ingesta possess the highest proportions of all studied elements, followed by species foraging on medium, medium-to-solid, soft-to-solid, and finally species feeding on soft ingesta.

Composition-type l: The highest Fe-proportions (means) were detected in the exclusively solid-, followed by the medium-to-solid-feeders. No Fe was detected for all other ingesta types.

Composition-type II and III: The highest proportions of Mg were detected in species foraging on medium ingesta, followed by solid-, soft-, medium-to-solid-, and finally soft-to-solid-feeders. Ca was detected in the highest proportions in the medium-, followed by the soft-, solid-, soft-to-solid-, and medium-to-solid-feeders. $\mathrm{P}$ was mainly found in species feeding on medium ingesta, followed by soft-to-solid-, solid-, medium-to-solid-, and finally soft-feeders. Cl was detected in the highest proportions in medium-feeders, followed by species feeding on soft-to-solid, soft, solid, and finally medium-to-solid ingesta. The highest proportions of F were found in radulae of medium-, followed by solid-, and finally medium-to-solid-feeders. In soft and soft-to-solid-feeders, no F was found.

Composition-type IV: The highest Si-content was detected in solid-, followed by medium-, medium-to-solid-, and finally soft-to-solid-feeders. No Si was found in species feeding on soft ingesta.

Composition-type V: The highest Cu proportions were detected in the solid-feeder Reymondia horei and less in the cephalopods foraging on soft-to-solid ingesta. All other radulae seem to lack $\mathrm{Cu}$.

$O B$ : S was detected in the highest proportions in species feeding on soft, followed by solid, soft-to-solid, medium-to-solid, and finally medium ingesta. The highest Na-proportions were detected in solid-, followed by the soft-, soft-to-solid-, medium-, and finally medium-to-solid-feeders. $\mathrm{K}$ was detected in the highest proportions in solid-, followed by medium-, medium-to-solid-, soft-to-solid-, and finally soft-feeders.

\section{Discussion}

A detailed list of previous studies aimed at determining the chemical composition of the molluscan radula is provided in Supplementary Table 2. Most of the previous research has been done on the Polyplacophora with the focus exclusively on the dominant lateral teeth [for reviews see 33-36, 46], except for one study on Lepidochitona cinerea determining the elemental composition of all toot types [32]. Many of these analyses focused on the Fe biomineralization and the phase transformations during maturation [e.g. 23, 29, 47-55]. Overall, in previous studies $\mathrm{F}, \mathrm{Na}, \mathrm{Mg}, \mathrm{Si}, \mathrm{P}, \mathrm{S}, \mathrm{Cl}, \mathrm{K}, \mathrm{Ca}, \mathrm{Fe}$, and $\mathrm{Cu}$ was detected in the dominant lateral teeth (=lateral teeth II) of Polyplacophora. For Lepidochitona cinerea, in our previous paper, we did not detect $\mathrm{Cl}$, $\mathrm{F}$, and $\mathrm{Cu}$ and in Acanthochitona fascicularis - no Si and $\mathrm{Cu}$.

The following Fe proportions of mature dominant lateral teeth were previously determined in Polyplacophora: for $A$. fascicularis - 59.2\% [56], 62\% [51, 57] or few percent [58] were detected. For Plaxiphora - 86.6\% [56], 17-27\% [51], or 26.7\% [59]; for Cryptochiton - 51.8\% [47] or 69\% [29]; for Ischnochiton - 62\% [51]; for Onithochiton - 66\% [51] or 0.2\% [59]; for Cryptoplax - 90 weight \% in the cap, 30 weight \% in the core, junction zone, and basis [49]; and for Chiton $97 \%$ [60] were detected. For mature L. cinerea, we previously [32] found Fe proportions of maximal 32\% (atomic ratio, atomic \%) and for A. fascicularis maximal $29 \%$ in the dominant lateral teeth.

For Polyplacophora, P was previously reported $[47,49,51,59,61]$ in form of iron phosphate $[52,62,63]$ or apatitic calcium phosphate $[58,59,61,64-66]$. $\mathrm{F}$ related to $\mathrm{Ca}[66,67]$ was also previously reported for the dominant lateral teeth of chitons. In Acanthopleura [51, 58] and Onithochiton [51], Ca was abundant to maximal $\sim 30$ elemental \% and $\mathrm{P}$ to maximal 20 elemental \%. For Lepidochitona cinerea, we detected Ca in proportions of maximal $8 \%$ and $\mathrm{P}$ to $7 \%$ and for Acanthochitona fascicularis to maximal $6 \%$ and $\mathrm{P}$ to $9 \%$.

Additionally, Si $[49,51,64,65]$ and $\mathrm{Mg}[51,59]$ were previously detected in the dominant lateral teeth of chitons. S was also previously detected [49]. It is associated with the tanning of the organic matrix and with the appearance of proteins [48]. Additionally, [68] detected Zi, K, F, S, Na, and $\mathrm{Cl}$ in radular segments 
of Clavarizona, [56] Ca, P, Mg, S, Na, Zi, K, Al, Cu, and Si in radulae of Acanthopleura and Plaxiphora, and [49] Mg (with max $~ 5.5$ weight \%), K (with max $\sim 1.0$ weight \%), $\mathrm{Na}$ (with max $\sim 2.0$ weight \%), Si (with max $\sim 1.0$ weight \%), Al (with max $\sim 0.5$ weight \%), and S (with max 0.8 weight \%) in Cryptoplax. These elements, except for $\mathrm{Zi}$ and $\mathrm{Cu}$, which were not found, occurred in smaller proportions (0-5\%) in both Lepidochitona cinerea and Acanthochitona fascicularis. For the central, lateral I, and marginal teeth we detected less minerals than in the dominant lateral teeth in both species.

In Cephalopoda, only one study on the radular chemistry exists, to the best of our knowledge. In Octopoda, [43] targeted, but did not detect Si and Fe. We here determined $\mathrm{Na}, \mathrm{S}, \mathrm{Cu}, \mathrm{Si}, \mathrm{P}, \mathrm{Cl}, \mathrm{Ca}$, and $\mathrm{Mg}$ in the radula of Histioteuthis spec. and Loligo vulgaris with proportions $<4 \%$.

Within the Gastropoda, the Patellogastropoda received the most attention [41-43, 56, 69-81]. However, few studies focused on the overall radular composition, since most analyses, e.g. ashing and treatments with different acids or Raman spectroscopies, EDX, rather targeted the presence and crystalline shape of Fe and Si [e.g. 41, 69, 70, 72-77, 80, 81]. In fewer studies, other elements were of interest [e.g. 42, 43, 56, 71, 78, 79]. Overall, in Patellogastropoda, Na, Mg, Si, P, Cl, K, Ca, Fe, Cu, and S were previously found. For Patella vulgata, we here detected $\mathrm{Na}, \mathrm{Mg}, \mathrm{Si}, \mathrm{P}, \mathrm{K}, \mathrm{Ca}, \mathrm{Fe}, \mathrm{S}$, but no Cu and Cl. We additionally determined F. Similar to previous studies, we detected Si and Fe in high proportions in the dominant teeth (18-38\%), whereas all other elements in smaller proportions only.

For the remaining gastropod taxa, only few analyses of the radular chemistry were conducted and usually the presence of elements, but not their proportions, could be determined. One of the earliest studies was done by [41] depicting results from Bergh, who performed complex chemical analyses of ashing and dissolving radulae from the Caenogastropods Charonia lampas (detecting P, Ca, and Fe), Lamellaria perspicua (detecting no Si), and Gibberulus gibberulus (probably detecting none of these elements, this is not clear) in different acids. Additionally, [41] presented his own results on the radulae of the Caenogastropod Tonna galea and the Heterobranch Helix nemoralis discovering P, Ca, and Fe in both by employing the same experiment. [42] was the first, who studied the radular chemistry in an elevated quantity of taxa and [43] proceeded. Overall, their protocols are rather complex, involving analytical chemistry methods (ashing, staining, boiling, treating with acids, and using diffusion column) or physics (radula's refractive index). [42] determined rather the presence of elements and [43] specifically tested the occurrence of Si and Fe. For the Caenogastropoda Potamopyrgus antipodarum, Lacuna vincta, Murex branchialis, and Aporrhais pespelecani, the Heterobranchia Scaphander lignarius, Aplysia punctata, and Jorunna tomentosa, [43] determined no Si and no Fe. For the Heterobranchia (Cornu aspersum), [42] determined Si and P. She detected Si in specimens collected during winter and phosphoric acid (P) in specimens collected during spring. [82] performed EDX analyses on five specimen of $C$. aspersum detecting $\mathrm{Ca}$ in all specimen and $\mathrm{Si}$ in one, even though specimens were also inventoried in spring depicting the inconsistency of elements embedded. For the Vetigastropoda (Haliotis tuberculata), [42] detected Si, Ca, and Fe.

The following species were studied by [42] and [43], but for many species their results are contradictory. In the Caenogastropoda Littorina littorea, [42] detected $\mathrm{Mg}, \mathrm{P}, \mathrm{Ca}$, and Fe, whereas [43] - no Ca and no Fe. Nucella lapillus and Buccinum undatum were also studied by [42], but the results are not clear from the publication, and [43] detected no Si and no Fe in both species. For the Vetigastropoda (Emarginula fissure and Calliostoma zizyphinum), [42] detected P, Ca, and Fe, whereas [43] determined the absence of Fe and Si. Then, [83] and [26, 84] were the first to close the existing gap in knowledge about the radular composition of Vetigastropoda. [83] detected $\mathrm{Na}, \mathrm{Mg}, \mathrm{Si}, \mathrm{Cl}, \mathrm{Ca}$, and $\mathrm{Fe}$ (EDX), and [26, 84] - Mg, Cl, Ca, and Fe (EDX and inductively coupled plasma-optical emission spectrometry) in the limpet Megathura crenulata. Within Vetigastropoda, we detected $\mathrm{Na}, \mathrm{S}, \mathrm{Cu}, \mathrm{Si}, \mathrm{P}, \mathrm{Cl}, \mathrm{Ca}$, and $\mathrm{Mg}$; all of them in low proportions $<2 \%$. Cu and $\mathrm{S}$ were not documented before, whereas Fe was detected in previous studies [83, 84]. For the Neritimorpha, only one past study addresses the mineral content detecting $\mathrm{S}, \mathrm{Cl}, \mathrm{K}, \mathrm{Ca}, \mathrm{Mg}, \mathrm{Si}$, and $\mathrm{Fe}$ [85]. We additionally detected $\mathrm{Na}$ and $\mathrm{P}$ in Vittina turrita; all elements detected are abundant in very low proportions (<4\%). In the Caenogastropoda, we detected Fe, Mg, Ca, Cl, P, F, Si, Cu, S, Na, and K. Cu, F, Na, Si, S, and Cl were not determined before. In all species, proportions are $<6 \%$. For the Heterobranchia, we detected more elements ( $\mathrm{Mg}, \mathrm{Ca}, \mathrm{Cl}, \mathrm{P}, \mathrm{F}, \mathrm{Si}, \mathrm{S}, \mathrm{Na}, \mathrm{K})$ than described in past publications [41-43, 82]. $\mathrm{Mg}, \mathrm{Cl}, \mathrm{F}, \mathrm{S}, \mathrm{Na}$, and $\mathrm{K}$ were not detected before. All elements are abundant at proportions $<15 \%$.

Overall, the above data depicts that it is rather difficult to compare the percentages measured between studies, because in some weight percentages and in others atomic ratios were determined. Besides, methodology, sample preparation, and the analyzed sample itself (whole radula or individual radular parts) differs. In addition, the presence and abundance of elements could potentially be influenced by the food available (e.g. plants containing or lacking Si) or by the chemistry of the saliva. In some taxa, specifically carnivorous gastropods, the saliva is acid [e.g. 86, 87], so potentially the contact of the outermost radular teeth with the saliva leads to reduced proportions. Both ideas await further research.

The generally accepted hypothesis on radular mineralization evolution states that all gastropods - besides Patellogastropoda, Neritimorpha, and Vetigastropoda - probably lack Fe in the radula [e.g. 88-90]. However, Fe was detected previously in gastropod species [for Tonna galea, Charonia lampas, and Helix nemoralis see 41, for Littorina littorea see 42] and our own analyses determined it in Reymondia horei and Littorina littorea. Thus, this means that iron is not lacking, rather its proportions are reduced in these gastropod lineages (see Figure 1).

Previous studies relate the radular length to the ingesta type. Herbivorous taxa were found to possess longer radulae than carnivorous ones [91]. Littorinid species, feeding on algae covering rocks, were found to possess longer radulae than species feeding from plant surface [92-96]. For Patella species, it was determined that the radular length increases with increasing usage and wear [97] and, when algae are less abundant and the radula must thus be used more frequently to obtain the food necessary, its length increases [98].

In general, we detected a similar pattern for the species studied here as the longest radulae with the highest quantity of tooth rows were found in species foraging on harder ingesta types (medium-to-solid, solid, medium) and the shortest ones in soft-substrate feeders. We, however, could not directly relate herbivory with longer radulae and carnivorous feeding with shorter ones. We additionally detected some relationship between radular length and proportions of elements (e.g. in Patella vulgata), so potentially more mineralized radulae are longer, because their maturation and mineralization requires more time and a longer contact to the overlain epithelia in the radular sac and mineralization zone. However, this does not seem to be the case for every species, as Lepidochitona cinerea and Acanthochitona fascicularis have relatively short heavily mineralized radulae. Thus, in these polyplacophoran species, the overlain epithelia can presumably incorporate more minerals at the same time or the radular replacement rate is faster in $P$. vulgata in contrast to the one in the 
Polyplacophora. Unfortunately, the radular replacement rate is known for few taxa: for Polyplacophorans (Acanthopleura, Plaxiphora, Patelloida, Mopalia), a rate of $0.36-0.80$ rows per day was determined $[56,99,100]$ and for $P$. vulgata, a rate of 1.5 rows/day was described [101]. In Caenogastropoda, for $L a c u n a$ (Littorinidae), the rate of 3 rows/day [102], for three Littorina species (Littorinidae) - 5-6 rows/day depending on the temperature [2, 101], and for Pomatias elegans - 5.02 rows/day [2] was determined. For Heterobranchia, the rate of 2.9 rows/day in Lymnaea stagnalis [103], 5.02 rows/day in Agriolimax reticulatus [2], 3.6 rows/day in adult Helix aspersa [= Cornu aspersum in 2] was detected. For Cepaea nemoralis, the whole radula was found to be renewed within 30-35 days [104]. Thus, in general, a higher degree of mineralization is inversely related to the higher replacement rate (teeth that possess larger proportions of minerals are replaced slower). However, radular replacement seems to depend on many factors, such as water temperature, metabolic rates, or age of animals $[101,102,105,106]$. Further studies on these questions are required.

In general, we detected that radulae of species, foraging on the solid ingesta, possess heavy mineralized teeth and species feeding on the soft ingesta show the smallest proportions. In biological materials, heterogeneities can have their origin in geometry, chemistry, and/or structure [for a review see 107]. In the dominant lateral teeth of chitons and limpets they have their origin in the distribution of the inorganic components and in the architecture of organic components $[23,25,27-31]$. We have previously correlated the hardness and elasticity values in Lepidochitona cinerea with the iron and the calcium proportions [32], which was previously also described for limpet teeth $[24,70,74,108]$ and for other chitons $[23,25,29,30]$. For the paludomid gastropods, we previously measured elasticity modulus values ranging from $2 \mathrm{GPa}$ at the tooth basis to $8 \mathrm{GPa}$ in the cusp in solid substrate feeders, whereas soft substrate feeders possessed significantly softer teeth $(4.6 \mathrm{GPa})[37,38,40]$. In these species, we here detected inorganic elements in rather small proportions. We thus propose that specific cross-linking conditions of the chitin due to tanning [1], fiber arrangement, and density [22, 23, 26, 28, 31, 54, 109-111] rather cause the heterogeneities in mechanical properties. We previously also detected that the capability of wet teeth to rely on one another and to redistribute the mechanical stress increases the radula's resistance to structural failure in paludomid gastropods [112,113]. This altogether probably enables the feeding on harder ingesta types. Whether these mechanisms are also applicable for the other molluscan species, await further investigations.

Table 1. Systematic position of the taxa studied, list of specimens with collection number, locality and date of collection or fixation. The ingesta preferred, if known, and the ingesta categories assigned in this study are listed. Radular parameters, i.e. type, formula, length, width, area, and quantity of tooth rows, are documented for each specimen. C, central tooth; DC, dominant central tooth; DT, dominant lateral tooth or lateral tooth II; TM, thickened membrane, potentially reduced central tooth. 


\begin{tabular}{|c|c|c|c|c|c|c|c|c|c|c|c|c|c|c|c|c|}
\hline \multirow[t]{2}{*}{ Class } & \multirow[t]{2}{*}{ Subclass } & \multirow[t]{2}{*}{ Species } & \multicolumn{4}{|c|}{ Specimens } & \multicolumn{3}{|c|}{ Ecology } & \multicolumn{6}{|c|}{ Radula } & \multirow[b]{2}{*}{$\begin{array}{l}N \text { c } \\
\text { toot } \\
\text { ron }\end{array}$} \\
\hline & & & $\begin{array}{c}N \text { of } \\
\text { specimens } \\
\text { studied } \\
\text { with EDX } \\
+ \text { SEM } \\
\end{array}$ & $\begin{array}{l}\text { Collection } \\
\text { number }\end{array}$ & $\begin{array}{l}\text { Source or } \\
\text { locality of } \\
\text { collection }\end{array}$ & $\begin{array}{c}\text { Date of } \\
\text { collection } \\
\text { or fixation }\end{array}$ & $\begin{array}{l}\text { Food or } \\
\text { substrate }\end{array}$ & $\begin{array}{c}\text { Reference for } \\
\text { ecology }\end{array}$ & $\begin{array}{l}\text { Ingesta } \\
\text { category }\end{array}$ & $\begin{array}{c}\text { Radular } \\
\text { type }\end{array}$ & $\begin{array}{l}\text { Radular } \\
\text { formula }\end{array}$ & $\begin{array}{l}\text { Specimen } \\
\text { no. }\end{array}$ & $\begin{array}{c}\text { Length, } \\
\mu \mathrm{m}\end{array}$ & $\begin{array}{c}\text { Width, } \\
\text { pm }\end{array}$ & $\begin{array}{l}\text { Area, } \\
\mu^{2}\end{array}$ & \\
\hline \multirow[t]{6}{*}{ Polyplacophora } & \multirow[t]{3}{*}{ Chitonida } & \multirow{3}{*}{$\begin{array}{l}\text { Lepidochitona } \\
\text { cinerea } \\
\text { (Linnaeus, 1767) }\end{array}$} & \multirow[t]{3}{*}{$3+1$} & \multirow{3}{*}{$\begin{array}{l}\text { ZMH } \\
154653\end{array}$} & \multirow{3}{*}{$\begin{array}{l}\text { North Sea, at } \\
\text { Husum, } \\
\text { Germany }\end{array}$} & \multirow{3}{*}{$\begin{array}{l}\text { Autumn } \\
2019\end{array}$} & \multirow{3}{*}{$\begin{array}{l}\text { Algae from } \\
\text { solid } \\
\text { substrate }\end{array}$} & \multirow[t]{3}{*}[156]{} & \multirow[t]{3}{*}{ Solid } & Docogloss & $1+\mathrm{DT}$ & 1 & 3375 & 375 & 1265625 & 3 \\
\hline & & & & & & & & & & & $\begin{array}{l}+1+C \\
+1+\end{array}$ & 2 & 3269 & 369 & 1206261 & -3 \\
\hline & & & & & & & & & & & DT +1 & 3 & 3109 & 354 & 1100586 & 3 \\
\hline & Chitonida & Acanthochitona & $2+1$ & \#will be & North Sea, at & 2018,2019 & Algae from & {$[157]$} & Solid & Docogloss & $1+\mathrm{DT}$ & 1 & 7630 & 890 & 6790700 & 5 \\
\hline & & $\begin{array}{l}\text { fascicularis } \\
\text { (Linnaeus, 1767) }\end{array}$ & & & $\begin{array}{l}\text { Roscoft, } \\
\text { Franee }\end{array}$ & & $\begin{array}{l}\text { solid } \\
\text { substrate }\end{array}$ & & & & $+1+\mathrm{C}$ & 2 & 7527 & 872 & 6566587 & 5 \\
\hline & & & & & & & & & & & $\mathrm{DT}+1$ & 3 & 7559 & 880 & 6652595 & 5 \\
\hline Cephalopoda & Oegopsida & $\begin{array}{l}\text { Histioteuthis spec. } \\
\text { d'Orbigny [in }\end{array}$ & 2 & $\begin{array}{l}\text { ZMH } \\
11623 / 999\end{array}$ & $\begin{array}{l}\text { NE Atlantic, } \\
46^{\circ} 29^{\prime} 24^{\prime \prime} \mathrm{N}\end{array}$ & 12.06.1982 & $\begin{array}{l}\text { Fish, } \\
\text { crustacea, }\end{array}$ & [158] & $\begin{array}{l}\text { Soft to } \\
\text { solid }\end{array}$ & Homodont & $\begin{array}{l}2+1+ \\
C+1+\end{array}$ & 1 & 868 & 464 & 402752 & 3 \\
\hline & & $\begin{array}{l}\text { Férussac \& } \\
\text { d'Orbigny], } 1841\end{array}$ & & & $\begin{array}{l}027^{\circ} 14^{\prime} 18^{\prime \prime} \mathrm{W} \\
-250 \mathrm{~m}\end{array}$ & & Cephalopoda & & & & 2 & 2 & 857 & 459 & 393363 & 3 \\
\hline & Myopsida & Loligo & $2+1$ & \#will be & Indonesia & Spring & Fish, & [159] & Soft to & Homodont & $2+1+$ & 1 & 6430 & 1480 & 9516400 & 4 \\
\hline & & vulgaris Lamarck, & & & & & crustacea, & & solid & & $C+1+$ & 2 & 6531 & 1485 & 9698535 & 4 \\
\hline & & 1798 & & & & & Cephalopoda & & & & 2 & 3 & 6315 & 1369 & 8645235 & 4 \\
\hline Gastropoda & Patellogastropoda & Patella & $2+1$ & \# will be & North Sea, at & 30.09 .2020 & Algae from & [160] & Solid & Docogloss & $3+\mathrm{DT}$ & 1 & 36634 & 949 & 34765666 & 19 \\
\hline & & $\begin{array}{l}\text { vulgata Linnaeus, } \\
1758\end{array}$ & & added & $\begin{array}{l}\text { Roscoff, } \\
\text { Franoe }\end{array}$ & & $\begin{array}{l}\text { rocks, } \\
\text { macroalgae }\end{array}$ & & & & $\begin{array}{l}+2+0 \\
+2+\end{array}$ & 2 & 36862 & 962 & 35461244 & 19 \\
\hline & & & & & & & & & & & $\mathrm{DT}+3$ & 3 & 35925 & 958 & 34416150 & 19 \\
\hline & Vetigastropoda & Rochia conus & $2+1$ & ZMH & Pet shop & Summer & Algae/ & www.sealifebase.ca & Solid & Rhipidogloss & $\infty+5+$ & 1 & 6070 & 980 & 5948600 & 10 \\
\hline & & & & & & & $\begin{array}{l}\text { plants from } \\
\text { corals and }\end{array}$ & & & & $\begin{array}{l}\mathrm{C}+5+ \\
\infty\end{array}$ & 2 & 6054 & 978 & 5920812 & 10 \\
\hline & & & & & & & rocks & & & & & 3 & 6103 & 968 & 5907704 & 10 \\
\hline & & Haliotis & $2+1$ & \#will be & Pet shop & Summer & Macroalgae & {$[161]$} & Medium & Rhipidogloss & $\infty+$ DT & 1 & 15945 & 3690 & 58837050 & 11 \\
\hline & & 1758 & & & & & & & & & $\begin{array}{l}+2+\mathrm{C} \\
+2+\end{array}$ & 2 & 15763 & 3598 & 56715274 & 11 \\
\hline & & & & & & & & & & & DT $+\infty$ & 3 & 15899 & 3304 & 52530296 & 11 \\
\hline & Neritimorpha & $\begin{array}{l}\text { Vittina turrita } \\
\text { (Gmelin, 1791) }\end{array}$ & $2+1$ & $\begin{array}{l}\text { ZMH } \\
154753\end{array}$ & Pet shop & $\begin{array}{l}\text { Summer } \\
2020\end{array}$ & $\begin{array}{l}\text { solid } \\
\text { substrates, }\end{array}$ & [162] & $\begin{array}{l}\text { Medium } \\
\text { to solid }\end{array}$ & $\begin{array}{l}\text { Rhipidogloss, } \\
\text { neritinomorph }\end{array}$ & $\begin{array}{l}40+1 \\
+1+C\end{array}$ & 1 & 17350 & 1210 & 20993500 & 15 \\
\hline & & & & & & & but also & & & & $+1+1$ & 2 & 17364 & 1205 & 20923620 & 15 \\
\hline & & & & & & & $\begin{array}{l}\text { porous } \\
\text { ingesta } \\
\end{array}$ & & & & & 3 & 18023 & 1305 & 23520015 & 14 \\
\hline & Caenogastropoda & Lavigeria grandis & $2+1$ & ZMH & Zambia & 30.11 .2017 & Algae from & [163-166] & Solid & Taeniogloss & $2+1+$ & 1 & 8120 & 900 & 7308000 & 8 \\
\hline & & (Smith, 1881) & & $150020 / 999$ & $08^{\circ} 43^{\prime} 25^{\prime \prime} \mathrm{S}$ & & rocks & & & & $C+1+$ & 2 & 8109 & 886 & 7184574 & 8 \\
\hline & & & & & $31^{\circ} 09^{\prime} 00^{\prime \prime} \mathrm{E}$ & & & & & & 2 & 3 & 7906 & 749 & 5921594 & 8 \\
\hline & & $\begin{array}{l}\text { Lavigeria nassa } \\
\text { (Woodward, 1859) }\end{array}$ & $2+1$ & $\begin{array}{l}\text { ZMH } \\
119369 / 999\end{array}$ & $\begin{array}{l}\text { Zambia } \\
08^{\circ} 29^{\prime} 23^{\prime \prime S}\end{array}$ & 09.09 .2016 & $\begin{array}{l}\text { Algae from } \\
\text { rocks }\end{array}$ & $\begin{array}{l}{[163,164,167-} \\
169] ; \text { personal }\end{array}$ & Solid & Taeniogloss & $\begin{array}{l}2+1+ \\
C+1+\end{array}$ & 1 & 5160 & 430 & 2218800 & 11 \\
\hline & & & & & $30^{\circ} 28^{\prime} 46^{\prime \prime} \mathrm{E}$ & & & comment from & & & & 2 & 5136 & 426 & 2187936 & 11 \\
\hline & & & & & & & & $\begin{array}{l}\text { Collector (Heinz } \\
\text { Büscher) }\end{array}$ & & & & 3 & 5004 & 435 & 2176740 & 11 \\
\hline & & Paramelania damoni & $2+1$ & & Zambia & 05.05 .2018 & Algae from & {$[163-166,168-172]$} & Soft to & Taeniogloss & $2+1+$ & 1 & 2060 & 388 & 799280 & 9 \\
\hline & & (Smith, 1881) & & $150023 / 999$ & $08^{\circ} 34^{\prime} 09^{\prime \prime} \mathrm{S}$ & & rocks and & & solid & & $C+1+$ & 2 & 2054 & 376 & 772304 & - \\
\hline & & & & & $31^{\circ} 45^{\prime} 02^{\prime \prime} \mathrm{E}$ & & sand & & & & 2 & 3 & 1786 & - & - & \\
\hline & & $\begin{array}{l}\text { Cleopatra johnstoni } \\
\text { Smith, } 1893\end{array}$ & $2+1$ & $\begin{array}{l}\text { ZMB } \\
220.102 b\end{array}$ & $\begin{array}{l}\text { Zambia } \\
09^{\circ} 20^{\prime} 866^{\prime} \mathrm{S}\end{array}$ & 19.12 .2000 & $\begin{array}{l}\text { Algae from } \\
\text { sand and }\end{array}$ & $\begin{array}{l}\text { Unpublished work, } \\
\text { personal comment }\end{array}$ & Soft & Taeniogloss & $\begin{array}{l}2+1+ \\
C+1+\end{array}$ & 1 & 2082 & 349 & 726618 & 7 \\
\hline & & & & & $28^{\circ} 43^{\prime} 886^{\prime} \mathrm{E}$ & & mud & & & & & 2 & 2076 & 347 & 720372 & 7 \\
\hline & & & & & & & & $\begin{array}{l}\text { from collector } \\
\text { (Matthias } \\
\text { Glaubrecht) } \\
\end{array}$ & & & & 3 & & 326 & & \\
\hline & & $\begin{array}{l}\text { Reymondia horei } \\
\text { (Smith, 1880) }\end{array}$ & $2+1$ & $\begin{array}{l}\text { ZMB } \\
220.147\end{array}$ & $\begin{array}{l}\text { Tanzania } \\
\text { Kigoma }\end{array}$ & 26. 02.1995 & $\begin{array}{l}\text { Algae from } \\
\text { rocks }\end{array}$ & $\begin{array}{l}\text { [163-166, 171, } \\
\text { 172]; } \\
\text { personal }\end{array}$ & Solid & Taeniogloss & $\begin{array}{l}2+1+ \\
\mathrm{C}+1+ \\
2\end{array}$ & 1 & 9240 & 820 & 7576800 & 17 \\
\hline & & & & & & & & $\begin{array}{l}\text { comment from } \\
\text { collectors (Heinz }\end{array}$ & & & & 2 & 9342 & 831 & 7763202 & 17 \\
\hline & & & & & & & & $\begin{array}{l}\text { Büscher and } \\
\text { Matthias } \\
\text { Glaubrecht) }\end{array}$ & & & & 3 & 9108 & 803 & 7313724 & 17 \\
\hline & & $\begin{array}{l}\text { Spekia zonata } \\
\text { (Woodward, 1859) }\end{array}$ & $2+1$ & $\begin{array}{l}\text { ZMB } \\
220.077\end{array}$ & $\begin{array}{l}\text { Zambia } \\
08^{\circ} 45^{\prime} 547^{\prime \prime} \mathrm{S}\end{array}$ & 12.02 .2000 & $\begin{array}{l}\text { Algae from } \\
\text { rocks }\end{array}$ & $\begin{array}{l}{[163-166,168,170-} \\
173] ;\end{array}$ & Solid & Taeniogloss & $\begin{array}{l}2+1+ \\
\mathrm{C}+1+\end{array}$ & 1 & 5660 & 560 & 3169600 & 13 \\
\hline & & & & & $31^{\circ} 05^{\prime} 825^{\prime \prime} \mathrm{E}$ & & & $\begin{array}{l}\text { personal comment } \\
\text { from collectors }\end{array}$ & & & & 2 & 5680 & 571 & 3243280 & 13 \\
\hline & & & & & & & & $\begin{array}{l}\text { Matthias } \\
\text { Glaubrecht) }\end{array}$ & & & & 3 & 5589 & 577 & 3224853 & 13 \\
\hline & & Faunus ater & $2+1$ & ZMH & Pet shop & Summer & ? found on & {$[174,175]$} & Soft to & Taeniogloss & $2+1+$ & 1 & 11480 & 510 & 5854800 & 17 \\
\hline & & (Linnaeus, 1758) & & 154630 & & 2019 & $\begin{array}{l}\text { soft and } \\
\text { solid }\end{array}$ & & solid? & & $\begin{array}{l}\mathrm{C}+1+ \\
2\end{array}$ & 2 & 11502 & 505 & 5808510 & 16 \\
\hline & & & & & & & substrate & & & & & 3 & 11899 & 489 & 5818611 & 17 \\
\hline & & $\begin{array}{l}\text { Littorina littorea } \\
\text { (Linnaeus, 1758) }\end{array}$ & $2+1$ & $\begin{array}{l}\text { ZMH } \\
154633\end{array}$ & $\begin{array}{l}\text { North Sea, at } \\
\text { Husum, }\end{array}$ & $\begin{array}{l}\text { Autumn } \\
2019\end{array}$ & $\begin{array}{l}\text { Algae, } \\
\text { fleshy }\end{array}$ & $\begin{array}{l}{[176,177,178,} \\
179]\end{array}$ & $\begin{array}{l}\text { Medium } \\
\text { to solid }\end{array}$ & Taeniogloss & $\begin{array}{l}2+1+ \\
C+1+\end{array}$ & 1 & 23180 & 370 & 8576600 & 28 \\
\hline & & & & & Germany & & macroalgae, & & & & 2 & 2 & 23195 & 376 & 8721320 & 28 \\
\hline
\end{tabular}




\begin{tabular}{|c|c|c|c|c|c|c|c|c|c|c|c|c|c|c|c|}
\hline & & & & & & $\begin{array}{l}\text { also from } \\
\text { rocks }\end{array}$ & & & & & 3 & & 384 & & \\
\hline & $\begin{array}{l}\text { Paludomus siamensis } \\
\text { Blanford, } 1903\end{array}$ & $2+1$ & $\begin{array}{l}\text { ZMB } \\
220.234\end{array}$ & $\begin{array}{l}\text { Thailand, } \\
\text { Kanchanaburi, } \\
14^{\circ} 26,3^{\prime} \mathrm{N} \\
98^{\circ} 51,0^{\prime} \mathrm{E}\end{array}$ & 08.02.2001 & Not known & ? & ? & Taeniogloss & $\begin{array}{l}2+1+ \\
C+1+ \\
2\end{array}$ & $1,2,3$ & & & & \\
\hline & \multirow{3}{*}{$\begin{array}{l}\text { Anentome helena } \\
\text { (von dem Busch, } \\
1847 \text { ) }\end{array}$} & \multirow[t]{3}{*}{$2+1$} & \multirow{3}{*}{$\begin{array}{l}\text { \#will be } \\
\text { added }\end{array}$} & \multirow[t]{3}{*}{ Pet shop } & \multirow{3}{*}{$\begin{array}{l}\text { Summer } \\
2019\end{array}$} & \multirow{3}{*}{$\begin{array}{l}\text { Gastropoda, } \\
\text { fish eggs, } \\
\text { shrimps, } \\
\text { carrion }\end{array}$} & \multirow[t]{3}{*}[180,181]{} & \multirow{3}{*}{$\begin{array}{l}\text { Soft to } \\
\text { solid }\end{array}$} & \multirow[t]{3}{*}{ Stenogloss } & \multirow{3}{*}{$\begin{array}{l}1+C+ \\
1\end{array}$} & 1 & 2097 & 244 & 511668 & 6 \\
\hline & & & & & & & & & & & 2 & 2102 & 241 & 506582 & 6 \\
\hline & & & & & & & & & & & 3 & 2189 & 261 & 571329 & 6 \\
\hline & \multirow{3}{*}{$\begin{array}{l}\text { Buccinum undatum } \\
\text { Linnaeus, } 1758\end{array}$} & \multirow[t]{3}{*}{$2+1$} & \multirow{3}{*}{$\begin{array}{l}\text { \# will be } \\
\text { added }\end{array}$} & \multirow{3}{*}{$\begin{array}{l}\text { Biologische } \\
\text { Anstalt } \\
\text { Helgoland, } \\
\text { Germany }\end{array}$} & \multirow[t]{3}{*}{ May 2021} & \multirow{3}{*}{$\begin{array}{l}\text { Polychaeta, } \\
\text { fish eggs, } \\
\text { bivalves, } \\
\text { carrion, etc. }\end{array}$} & \multirow[t]{3}{*}{ [182] } & \multirow{3}{*}{$\begin{array}{l}\text { Soft to } \\
\text { solid }\end{array}$} & \multirow[t]{3}{*}{ Stenogloss } & \multirow{3}{*}{$\begin{array}{l}1+C+ \\
1\end{array}$} & 1 & 9660 & 1420 & 13717200 & 5 \\
\hline & & & & & & & & & & & 2 & 9641 & 1396 & 13458836 & 6 \\
\hline & & & & & & & & & & & 3 & 9701 & 1486 & 14415686 & 6 \\
\hline \multirow[t]{15}{*}{ Heterobranchia } & \multirow{3}{*}{$\begin{array}{l}\text { Onchidoris } \\
\text { bilamellata } \\
\text { (Linnaeus, 1767) }\end{array}$} & \multirow[t]{3}{*}{$2+1$} & \multirow{3}{*}{$\begin{array}{l}\text { \#will be } \\
\text { added }\end{array}$} & \multirow{3}{*}{$\begin{array}{l}\text { Biologische } \\
\text { Anstalt } \\
\text { Helgoland, } \\
\text { Germany }\end{array}$} & \multirow[t]{3}{*}{ May 2021} & \multirow{3}{*}{$\begin{array}{l}\text { Soft parts of } \\
\text { barnacles }\end{array}$} & \multirow[t]{3}{*}[4,183]{} & \multirow[t]{3}{*}{ Medium } & & $1+\mathrm{DT}$ & 1 & 2060 & 447 & 920820 & 3 \\
\hline & & & & & & & & & & $+\mathrm{TM}+$ & 2 & 2081 & 461 & 959341 & 3 \\
\hline & & & & & & & & & & & 3 & . & 474 & - & \\
\hline & Aeolidia papillosa & $2+1$ & \# will be & Biologische & May 2021 & Sea & [184-186] & Soft & & $\mathrm{DC}$ & 1 & 1460 & 410 & 598600 & \\
\hline & (Linnaeus, 1761) & & added & Anstalt & & anemone & & & & & 2 & 1471 & 420 & 617820 & \\
\hline & & & & Germany & & & & & & & 3 & 1507 & 429 & 646503 & 1 \\
\hline & Polycera & $2+1$ & \# will be & Biologische & May 2021 & Encrusted & [187] & Medium & & $1+1+$ & 1 & 2075 & 726 & 1506450 & 1 \\
\hline & quadrilineata & & added & Anstalt & & Bryozoa & & & & $\mathrm{TM}+1$ & 2 & 2082 & 731 & 1521942 & 1 \\
\hline & & & & Germany & & & & & & & 3 & & & & \\
\hline & Doris pseudoargus & $2+1$ & \# will be & Biologische & May 2021 & Porifera & {$[188,189]$} & Medium & Isodont & $\infty+\infty+$ & 1 & 2350 & 2520 & 5922000 & 2 \\
\hline & Rapp, 1827 & & added & Anstalt & & & & & & $C+\infty+$ & 2 & 2461 & 2580 & 6349380 & 2 \\
\hline & & & & $\begin{array}{l}\text { Helgoland, } \\
\text { Germany }\end{array}$ & & & & & & $\infty$ & 3 & & 知 & & \\
\hline & Cornu aspersum & $2+1$ & ZMH & Pet shop & 2018 & Various & www.cabi.org/isc/ & Soft to & Isodont & $\infty+\infty+$ & 1 & 8000 & 3000 & 24000000 & 17 \\
\hline & (Müller, 1774) & & 150005 & & & plant types & datasheet/26821 & solid & & $\mathrm{C}+\infty+$ & 2 & 8123 & 3004 & 24401492 & 18 \\
\hline & & & & & & & & & & $\infty$ & 3 & 8206 & 3208 & 26324848 & 17 \\
\hline
\end{tabular}

Table 2. Proportions of elements, radular length, area, quantity of tooth rows for the species foraging on certain ingesta types. N, quantity of teeth that contain the elements or quantity of radulae studied.

\begin{tabular}{|c|c|c|c|c|c|c|c|c|c|c|c|c|c|c|c|}
\hline \multirow[b]{3}{*}{ Parameter } & \multicolumn{15}{|c|}{ Ingesta type } \\
\hline & \multicolumn{3}{|c|}{ Soft } & \multicolumn{3}{|c|}{ Soft to solid } & \multicolumn{3}{|c|}{ Medium } & \multicolumn{3}{|c|}{ Medium to solid } & \multicolumn{3}{|c|}{ Solid } \\
\hline & Mean & SD & $N$ & Mean & SD & $N$ & Mean & SD & $N$ & Mean & SD & $N$ & Mean & SD & $N$ \\
\hline Proportions of all elements, atomic \% & 1.88 & 2.80 & $\begin{array}{l}64 / \\
64\end{array}$ & 2.99 & 2.40 & $\begin{array}{l}348 / \\
348\end{array}$ & 5.58 & 6.24 & $\begin{array}{l}164 / \\
164\end{array}$ & 3.97 & 2.39 & $\begin{array}{l}122 / \\
122\end{array}$ & 6.33 & 12.50 & $\begin{array}{l}688 / \\
688\end{array}$ \\
\hline Radular length, $\mu \mathrm{m}$ & 1964.00 & 241.55 & 5 & 5901.28 & 3945.67 & 20 & 7704.29 & 6710.08 & 9 & 20128.88 & 2923.74 & 5 & 7911.95 & 8319.09 & 24 \\
\hline Radular area, $\mu^{2}$ & 702397 & 45924 & 5 & 7406442 & 7723878 & 19 & 25206904 & 26887891 & 9 & 15106455 & 6172958 & 5 & 6144306 & 8488474 & 24 \\
\hline$N$ of tooth rows & 59 & 24 & 5 & 92 & 53 & 20 & 62 & 43 & 9 & 241 & 38 & 5 & 97 & 53 & 24 \\
\hline Fe-proportion, atomic \% & 0.00 & 0.00 & $\begin{array}{l}0 / \\
64\end{array}$ & 0.00 & 0.00 & $\begin{array}{l}0 / \\
348\end{array}$ & 0.00 & 0.00 & $\begin{array}{l}\text { o/ } \\
164\end{array}$ & 0.34 & 0.15 & $\begin{array}{l}62 / \\
122\end{array}$ & 13.69 & 10.17 & $\begin{array}{l}120 / \\
688\end{array}$ \\
\hline Mg-proportion, atomic \% & 0.34 & 0.24 & $\begin{array}{l}41 / \\
64\end{array}$ & 0.15 & 0.11 & $\begin{array}{l}237 / \\
348 \\
\end{array}$ & 0.68 & 0.43 & $\begin{array}{l}114 / \\
164\end{array}$ & 0.28 & 0.27 & $\begin{array}{l}85 / \\
122 \\
\end{array}$ & 0.42 & 0.62 & $\begin{array}{l}426 / \\
688 \\
\end{array}$ \\
\hline Ca-proportion, atomic \% & 3.11 & 2.49 & $\begin{array}{l}12 / \\
64\end{array}$ & 1.22 & 1.27 & $\begin{array}{l}317 / \\
348\end{array}$ & 3.15 & 3.22 & $\begin{array}{l}150 / \\
164\end{array}$ & 1.12 & 1.03 & $\begin{array}{l}118 / \\
122\end{array}$ & 1.84 & 1.80 & $\begin{array}{l}561 / \\
688\end{array}$ \\
\hline P-proportion, atomic \% & 0.69 & 0.95 & $\begin{array}{l}22 / \\
64\end{array}$ & 1.29 & 1.12 & $\begin{array}{l}264 / \\
348\end{array}$ & 1.91 & 2.06 & $\begin{array}{l}132 / \\
164\end{array}$ & 0.63 & 0.62 & $\begin{array}{l}112 / \\
122\end{array}$ & 1.11 & 1.64 & $\begin{array}{l}405 / \\
688\end{array}$ \\
\hline Cl-proportion, atomic \% & 0.26 & 0.43 & $\begin{array}{l}27 / \\
64\end{array}$ & 0.42 & 0.41 & $\begin{array}{l}256 / \\
348\end{array}$ & 0.98 & 0.27 & $\begin{array}{l}6 / \\
164 \\
\end{array}$ & 0.16 & 0.18 & $\begin{array}{l}66 / \\
122 \\
\end{array}$ & 0.21 & 0.15 & $\begin{array}{l}248 / \\
688 \\
\end{array}$ \\
\hline F-proportion, atomic \% & 0.00 & 0.00 & $\begin{array}{l}0 / \\
64 \\
\end{array}$ & 0.00 & 0.00 & $\begin{array}{l}0 / \\
348 \\
\end{array}$ & 0.65 & 0.74 & $\begin{array}{l}136 / \\
164 \\
\end{array}$ & 0.28 & 0.24 & $\begin{array}{l}44 / \\
122 \\
\end{array}$ & 0.38 & 0.48 & $\begin{array}{l}156 / \\
688 \\
\end{array}$ \\
\hline Si-proportion, atomic \% & 0.00 & 0.00 & $\begin{array}{l}0 / \\
64\end{array}$ & 0.22 & 0.20 & $\begin{array}{l}116 / \\
348\end{array}$ & 0.74 & 0.58 & $\begin{array}{l}24 / \\
164\end{array}$ & 0.50 & 0.46 & $\begin{array}{l}120 / \\
122\end{array}$ & 7.39 & 10.40 & $\begin{array}{l}83 / \\
688\end{array}$ \\
\hline Cu-proportion, atomic \% & 0.00 & 0.00 & $\begin{array}{l}0 / \\
64 \\
\end{array}$ & 0.19 & 0.12 & $\begin{array}{l}94 / \\
348\end{array}$ & 0.00 & 0.00 & $\begin{array}{l}\text { 0/ } \\
164\end{array}$ & 0.00 & 0.00 & $\begin{array}{l}0 / \\
122 \\
\end{array}$ & 0.33 & 0.17 & $\begin{array}{l}521 \\
688 \\
\end{array}$ \\
\hline S-proportion, atomic \% & 0.62 & 1.05 & $\begin{array}{l}40 / \\
64\end{array}$ & 0.36 & 0.25 & $\begin{array}{l}241 / \\
348\end{array}$ & 0.22 & 0.20 & $\begin{array}{l}69 / \\
164 \\
\end{array}$ & 0.32 & 0.20 & $\begin{array}{l}104 / \\
122\end{array}$ & 0.38 & 0.52 & $\begin{array}{l}349 / \\
688\end{array}$ \\
\hline Na-proportion, atomic \% & 0.38 & 0.28 & $\begin{array}{l}58 / \\
64\end{array}$ & 0.22 & 0.22 & $\begin{array}{l}174 / \\
348\end{array}$ & 0.22 & 0.31 & $\begin{array}{l}69 / \\
164\end{array}$ & 0.14 & 0.12 & $\begin{array}{l}64 / \\
122\end{array}$ & 0.66 & 0.70 & $\begin{array}{l}230 / \\
688\end{array}$ \\
\hline K-proportion, atomic \% & 0.02 & 0.01 & $\begin{array}{l}14 / \\
64\end{array}$ & 0.08 & 0.08 & $\begin{array}{l}24 / \\
348\end{array}$ & 0.09 & 0.08 & $\begin{array}{l}10 / \\
164\end{array}$ & 0.09 & 0.08 & $\begin{array}{l}6 / \\
122\end{array}$ & 0.39 & 0.40 & $\begin{array}{l}40 / \\
688\end{array}$ \\
\hline
\end{tabular}

\section{Methods}

\section{Specimen studied and dissection}

Mollusks were obtained from various sources (see Tab. 1 for details): individuals of Littorina littorea and Lepidochitona cinerea were collected at the North Sea in summer 2019 and those of Patella vulgata in autumn 2020. The gastropods Cornu aspersum, Rochia conus, Haliotis tuberculata, Vittina turrita, Faunus 
ater, and Anentome helena were bought from online pet shops. All of them were shortly boiled and preserved in 70\% ethanol. Individuals of Aeolidia papillosa, Onchidoris bilamellata, Polycera quadrilineata, and Doris pseudoargus were received from the Biologische Anstalt Helgoland in May 2021, kept in aquarium for 2 weeks in Hamburg, before the gastropods naturally died and then were preserved in $70 \%$ ethanol. Frozen specimens of Loligo vulgaris were bought from Fische Schmidt (store specialized on edible fish, Eppendorfer Baum 18, 20249 Hamburg) for the dissection course of the Universität Hamburg, radulae were directly extracted from defrozen squids and preserved in 70\% ethanol. Samples of Lavigeria grandis, L. nassa, Paramelania damoni, Cleopatra johnstoni, Reymondia horei, Spekia zonata, Paludomus siamensis, Buccinum undatum, Acanthochitona fascicularis, Histioteuthis sp. were extracted from already preserved (70\% ethanol) specimens, some of them already inventoried in museum collections (Zoologisches Museum Hamburg, ZMH; Museum für Naturkunde Berlin, ZMB).

Species identification was reviewed by employing the relevant literature, the nomenclature and systematic position were checked using molluscabase.org. Not previously inventoried specimens were incorporated in the malacological collection of the ZMH, which is now part of the Leibniz-Institut für die Analyse des Biodiversitätswandels (LIB).

Overall, data from 72 adult specimens were analyzed for this study. For each species, three adult specimens were selected, except for Histioteuthis spec. with two. We have chosen specimens of similar size per species, since the relationship between specimens' length and radular size is puzzling. Some previous studies relate both parameters [114] and others rather see a loose relationship or could not relate them for every species [91, 115]. Additionally, the specimens chosen for each species were collected at the same time since seasonal dependencies in radular length were previously reported [18]. All data presented here is new, except for the elemental composition and radular morphology of Lepidochitona cinerea, which was taken from [32]. In this previous study, we analysed the ontogeny of the elemental composition and the mechanical parameters hardness and elasticity in three specimens of $L$. cinerea. For the present study, we included only the data from the working zone (the mature part) for the purpose of comparison between species.

Habitus images were either taken employing the Keyence Digital Microscope VHX-5000 (KEYENCE, Neu-lsenburg, Germany) or by using an iPad Pro (11 zoll; Apple Inc., Cupertino, USA) equipped with a 12-megapixel wide angle lens. Each specimen was dissected, the radula was carefully extracted by tweezers and then manually freed from surrounding tissue.

\section{Scanning electron microscopy (SEM)}

For images of the whole radula or the radular working zone, radulae (three per species, except for Histioteuthis spec. with two) were cleaned in an ultrasonic bath for 2-20 seconds and afterwards arranged on scanning electron microscopy (SEM) sample holders (see Supplementary Figures 1-24). All radulae were first documented with the Keyence Digital Microscope VHX-5000 or VHX-7000 (KEYENCE, Neu-Isenburg, Germany). Here the length and width of each radula were measured and the quantity of tooth rows counted. From the length and width, the radular area was calculated. Two radulae per species were then visualized uncoated employing the Tabletop Microscope TM 4000 Plus (Hitachi, Tokyo, Japan) for more detailed images and one radula per species was coated and documented with the Zeiss LEO 1525 (One Zeiss Drive, Thornwood, USA) to receive images with a very high resolution (except for images of $L$. cinerea, they were taken from [116], and of $H$. spec., as their radulae were documented uncoated and afterwards used for the EDX). Based on the morphology and arrangement of teeth, which were also categorized (e.g. central tooth, lateral tooth I, lateral tooth II, marginal tooth, inner teeth, outer teeth, etc.) according to their shape, size, and position on the membrane, radulae were assigned to different radular types (e.g. docogloss, isodont, rhipidogloss, etc.), if a suitable category could be determined from literature [e.g. 5, 117-120]. Then, the radulae, which were previously documented uncoated (two per species), were rewetted with $70 \%$ ethanol and loosened from the SEM sample holder and used for elemental analysis.

\section{Elemental analysis (EDX)}

Wet radulae were arranged on glass object slides (Carl Roth, Karlsruhe, Germany) with double-sided adhesive tape. They were positioned along their longitudinal axis so that the outermost teeth of one side were directly attached to the slide. The adjacent and more inner teeth were located above, followed by the central teeth, the inner teeth from the other side, and finally, on top, outer teeth again. Each radula was then dried for three days under ambient temperature and afterwards surrounded with a small, metallic ring ensuring an almost parallel sample surface. Epoxy resin (RECKLIEPOXIWST, RECKLI GmbH, Herne, Germany) was filled into the metallic ring and left polymerizing at room temperature for three days. This specific epoxy was chosen, since it does not infiltrate the teeth. Object slide and tape were then removed and, to receive longitudinal sections of each tooth, the embedded radulae were polished until the outer teeth were on display (controlled by examining the samples in the light microscope) using sandpapers of different roughness. Then samples were smoothed with aluminum oxide polishing powder suspension of $0.3 \mu \mathrm{m}$ grainsize (PRESI GmbH, Hagen, Germany) on a polishing machine (Minitech 233/333, PRESI GmbH, Hagen, Germany). After polishing, the samples were cleaned from the polishing powder by an ultrasonic bath lasting five minutes. Samples were then coated with platinum ( $5 \mathrm{~nm}$ layer) and the elemental compositions of specific areas of the embedded teeth were examined employing the SEM Zeiss LEO 1525 (One Zeiss Drive, Thornwood, New York, USA) equipped with an Octane Silicon Drift Detector (SDD) (micro analyses system TEAM, EDAX Inc., New Jersey, USA) always using an acceleration voltage of $20 \mathrm{keV}$ and the same settings (e.g. lens opening, working distance, etc.). Before measuring a sample the detector was always calibrated using cupper. We performed elemental mappings for test purposes, but for elements that are present in rather lower proportions, this method is not sensitive enough. We thus focused on the elemental analysis of small areas $\left(10-400 \mu \mathrm{m}^{2}\right.$, depending on the tooth) trying to analyze the largest possible area.

The elements H (hydrogen), C (carbon), N (nitrogen), O (oxygen), Pt (platinum), Al (aluminum), Ca (calcium), Na (sodium), Mg (magnesium), Si (silicon), P (phosphorus), S (sulphur), Cl (chlorine), K (potassium), F (fluorine), $\mathrm{Cu}$ (copper), and Fe (iron) were detected and their proportions measured. We used the data 
of atomic ratio (atomic \%) for this study. These values were received with two positions after the decimal point, lower proportions were not detectable with this method and therefore they were given as 0.00 . We did not analyze and discuss the following elements, as they are either the elemental basis of chitin $(\mathrm{H}, \mathrm{C}, \mathrm{N}$, $0)$, the coating $(\mathrm{Pt})$, or the polishing powder $(\mathrm{Al}, \mathrm{O})$.

After analyzing the outer teeth, each sample was again polished and smoothened until the next tooth type was on display; cleaning procedure and EDX analyses were again performed. These steps were repeated until all teeth were analyzed. In this study, we present the results of the radular working zone, which is not covered by epithelia and mature. Overall, we use data of 1448 analyzed teeth from 49 specimens.

\section{Statistical analyses}

All statistical analyses (mean, standard deviations) and visualizations with boxplots, pie charts, or trend lines were performed with JMP Pro, Version 14 (SAS Institute Inc., Cary, NC, 1989-2007).

\section{Composition- and biomineralization-types}

With EDX analysis, the proportions of the individual elements, present in a defined area, can be documented, whereas the specific bonding and structure of molecules cannot be analyzed. However, from the percentile occurrence, in comparison with past studies on the radular chemical composition involving, we propose that the elements, detected here, are potentially part of the following molecules or minerals. These were assigned to different composition- or biomineralization-types:

Category Type 1: Characterized by the presence of Fe. Potentially present in the form of magnetite as documented in polyplacophoran or goethite in limpets [e.g. 30, 31, 65, 75, 121-125).

Category Type 2: Characterized by the presence of $\mathrm{Mg}$ and $\mathrm{Ca}$. Elements are potentially involved in the protein packing, an increase in density of chitin fibers and in material stiffness as documented in limpet teeth [26].

Category Type 3: Characterized by the presence of $\mathrm{Ca}, \mathrm{P}, \mathrm{Cl}$ and/or $\mathrm{F}$. These elements (Ca:P:Cl/F) occur approximately in these ratios to one another: 5:3:1. They are potentially part of apatite, either fluorapatite, $\mathrm{Ca}_{5}\left[\mathrm{Fl}\left(\mathrm{PO}_{4}\right)_{3}\right]$, or chlorapatite, $\mathrm{Ca}_{5}\left[\mathrm{Cl}_{(}\left(\mathrm{PO}_{4}\right)_{3}\right]$ as previously described for radular teeth of polyplacophorans [e.g. 51, 56, 57, 61, 64, 126-128].

Category Type 4: Characterized by the presence of Si. Potentially present in the form of silica as documented in limpet teeth [e.g. 46, 81].

Category Type 5: Characterized by the presence of $\mathrm{Cu}$.

Category $O B$ (organic bonds): The presence of $\mathrm{Na}, \mathrm{K}$, and $\mathrm{S}$ is often related to the protein bonding [e.g. 129, 130].

\section{Ingesta categories}

The precise trophic preference of molluscan species is completely understudied. Some past approaches on various molluscan species determining the food preferences were based on the analysis of ingesta consumption, grazing activity, food choice experiments, stomach content, and fecal analyses [e.g. 10, 131, 132-143]. These studies overall show, that very various food types can be intaken by one individual species. However, this cannot be generalized, since some taxa are less flexible with regard to the ingesta intaken [e.g. Nudibranchia, see 144].

For this study, we defined ingesta categories that are rather broad, because (a) either the species' food preference has only been described anecdotally and (b) even if the specific food type was known, its precise mechanical properties and its structural resistance to feeding is difficult to determine [see 145, 146] and that is why these properties remain unknown. We collated the data on ingesta from the literature, if available, and assigned it to the following ingesta categories (please, see Table 1 for food types per species and corresponding references):

Soft. Algae from sand or mud, sea anemones.

Medium: Macroalgae, soft parts of barnacles, encrusted Bryozoa, or Porifera.

Solid: Algae/plants from rocks and/or corals.

Soft to solid: Fish, crustaceans, and cephalopods; algae from rocks and sand; gastropods, fish eggs, shrimps, and carrion; polychaeta, fish eggs, bivalves, carrion, etc.

Medium to solid: Algae, fleshy macroalgae, also from rocks. 
The cladogram, depicting the systematic position of the species studied, was created by combining data from published phylogenies [12, 147-155] with data on the latest systematic position of the species from molluscabase.org.

\section{Declarations}

\section{Authors' contribution}

WK and SG together initiated the project, designed the study, and discussed the data. In the course of his master thesis, JOB performed EDX analyses of six species and collated the literature. WK together with JOB wrote the first draft of the manuscript. WK executed the remaining EDX analyses and created the figures. All authors contributed to and approved the final version of the manuscript for publication.

\section{Acknowledgements}

We would like to thank Renate Walter and Elke Woelken from the Zoological Institute, Universität Hamburg (UHH), Germany, for their support with the SEM and Thomas Schwaha from the Universität Wien, Austria, for identifying specimens of Acanthochitona fascicularis and providing their habitus images. We are grateful for the help of the members from the department "Functional Morphology and Biomechanics", Christian-Albrechts-Universität zu Kiel (CAU), Germany, for collecting individuals of Lepidochitona cinerea and Littorina littorea at Husum during the annual work outing, Marco T. Neiber from the UHH for his support on species identification, and Thomas M. Kaiser from the Leibniz Institute for the Analysis of Biodiversity Change (LIB), Hamburg, Germany, for some discussion on the results. We thank Frank Friedrich from the Zoological Institute (UHH) for supervising the master thesis of OB, serving as basis for this study, and his advices on EDX data interpretation, Alexandra Kerbl from the University of Exeter, UK, and Lenke Tödter from the LIB for collecting individuals of Patella vulgata, Ute Kieb from the Alfred-Wegener-Institute from Helgoland for providing specimens of Buccinum and individuals of Aeolidia, Onchidoris, Polycera, and Doris. We are grateful for the access to Ilka Sötje's highly equipped lab at the UHH, which enabled us to keep and feed the nudibranch mollusks, and her expertise on the preservation of marine invertebrates, the lecturers of the students' dissection course from the UHH and LIB for reserving Loligo's radulae and beaks, Heinz Büscher from Basel, Switzerland, for collecting specimens of the Paludomidae at Lake Tanganyika, and Bernhard Hausdorf from the LIB for providing access to Histioteuthis specimens. We are grateful for the technical support of Esther Appel and Alexander Kovalev from the Department "Functional Morphology and Biomechanics" (CAU) at the beginning of the study, and the helpful comments of the anonymous reviewers.

\section{Competing interests}

The authors declare no competing interest.

\section{Funding}

This research did not receive any specific grant from funding agencies in the public, commercial, or not-for-profit sectors.

\section{References}

1. N. Runham, J. Cell. Sci. 1963, 3, 271.

2. N. Runham, K. Isarankura, Malacologia 1966, 5, 73.

3. U. Mackenstedt, K. Märkel, in The biology of terrestrial molluscs (Ed: G. M. Barker), CABI Publishing, Oxon, United Kingdom 2001, Ch. 4.

4. D. M. Crampton, Trans. Zool. Soc. London 1977, 34, 45.

5. R. S. Steneck, L. Watling, Mar. Biol. 1982, 68, 299.

6. K. R. Jensen, Evol. Ecol. 1997, 11, 301.

7. M. Nishi, A. J. Kohn, J. Molluscan Stud. 1999, 65, 483.

8. T. F. Duda, A. J. Kohn, S. R. Palumbi, Biol. J. Linn. Soc. Lond. 2001, 73, 391.

9. T. von Rintelen, A. B. Wilson, A. Meyer, M. Glaubrecht, Proc. R. Soc. B 2004, 271, 2541.

10. I. Ekimova, Á. Valdés, A. Chichvarkhin, T. Antokhina, T. Lindsay, D. Schepetov, Mol. Phylogenet. Evol. 2019, 141, 106609.

11. A. Mikhlina, I. Ekimova, E. Vortsepneva, Zoology 2020, 143, 125850.

12. W. Krings, Dissertation Thesis, Universität Hamburg 2020

13. W. Krings, J.-O. Brütt, S. N. Gorb, M. Glaubrecht, Malacologia 2020, 63, 77.

14. J. S. Bleakney, Veliger 1990, 33, 111.

15. K. R. Jensen, Biol. J. Linn. Soc. Lond. 1993, 48, 135.

16. D. G. Reid, Y.-M. Mak, J. Molluscan Stud. 1999, 65, 355.

17. D. K. Padilla, E. K. Dilger, D. E. Dittmann, Am. Zool. 2000, 40, 1161.

18. A. Ito, A. S. Ilano, S. Goshima, S. Nakao, J. Molluscan Stud. 2002, 68, 197. 
19. D. K. Padilla, Am. Malacol. Bull. 2003, 18, 163.

20. W. Krings, S. N. Gorb, Biotribology 2021, 26, 100164.

21. W. Krings, C. Hempel, L. Siemers, M. T. Neiber, S. N. Gorb, Sci. Rep. 2021, 11, 9556.

22. D. Lu, A. H. Barber, J. Royal Soc. Interface 2012, 9, 1318.

23. L. K. Grunenfelder, E. E. de Obaldia, Q. Wang, D. Li, B. Weden, C. Salinas, R. Wuhrer, P. Zavattieri, D. Kisailus, Adv. Funct. Mater. $2014,24,6093$.

24. A. H. Barber, D. Lu, N. M. Pugno, J. Royal Soc. Interface 2015, 12, 20141326.

25. S. A. Herrera, L. Grunenfelder, E. Escobar, Q. Wang, C. Salinas, N. Yaraghi, J. Geiger, R. Wuhrer, P. Zavattieri, D. Kisailus, Stylus support structure and function of radular teeth in Cryptochiton stelleri, 20th International Conference on Composite Materials Copenhagen, 19-24th July, 2015.

26. T. Ukmar-Godec, L. Bertinetti, J. W. C. Dunlop, A. Godec, M. A. Grabiger, A. Masic, H. Nguyen, I. Zlotnikov, P. Zaslansky, D. Faivre, Adv. Mater. 2017, 29, 1701171.

27. A. Pohl, S. A. Herrera, D. Restrepo, R. Negishi, J.-Y. Jung, C. Salinas, R. Wuhrer, T. Yoshino, J. McKittrick, A. Arakaki, M. Nemoto, P. Zavattieri, D. Kisailus, J. Mech. Behav. Biomed. Mater. 2020, 111, 103991.

28. L. Stegbauer, P. J. M. Smeets, R. Free, S. G. Wallace, M. C. Hersam, E. E. Alp, D. Joester, PNAS 2021, 118, e2020160118.

29. J. C. Weaver, Q. Wang, A. Miserez, A. Tantuccio, R. Stromberg, K. N. Bozhilov, P. Maxwell, R. Nay, S. T. Heier, E. DiMasi, Mater. Today $2010,13,42$.

30. Q. Wang, M. Nemoto, D. Li, J. C. Weaver, B. Weden, J. Stegemeier, K. N. Bozhilov, L. R. Wood, G. W. Milliron, C. S. Kim, E. DiMasi, D. Kisailus, Adv. Funct. Mater. 2013, 23, 2908.

31. T. Ukmar-Godec, in Iron Oxides: From nature to applications (Eds: D. Faivre, R.B. Frankel), Wiley-VCH, Weinheim, Germany $2016, \mathrm{Ch} .9$.

32. W. Krings, J.-O. Brütt, S. N. Gorb, Ontogeny of the elemental composition and the biomechanics of radular teeth in the chiton Lepidochitona cinerea. Under review at Frontiers in Zoology (2022).

33. L. R. Brooker, J. A. Shaw, in Advanced topics in biomineralization (Ed: J. Seto), Intech Open, Rijeka, Croatia 2012, Ch. 4.

34. D. Joester, L. R. Brooker, in Iron oxides: From nature to applications (Eds: D. Faivre, R.B. Frankel), Wiley-VCH, Weinheim, Germany $2016, \mathrm{Ch} .8$.

35. D. Kisailus, M. Nemoto, in Biological magnetic materials and applications (Eds: T. Matsunaga, T. Tanaka, D. Kisailus), Springer, Singapore 2018 , Ch. 1.

36. H. M. Moura, M. M. Unterlass, Biomimetics 2020, 5, 29.

37. W. Krings, A. Kovalev, M. Glaubrecht, S. N. Gorb, Zoology 2019, 137, 125713.

38. W. Krings, M. T. Neiber, A. Kovalev, S. N. Gorb, M. Glaubrecht, BMC Ecol. Evol. 2021, 21, 35.

39. W. Krings, J. Marcé-Nogué, S. N. Gorb, Sci. Rep. 2021, 11, 22775.

40. S. N. Gorb, W. Krings, Acta Biomater. 2021, 134, 513.

41. F. H. Troschel, Das Gebiss Der Schnecken Zur Begründung Einer Natürlichen Classification, Nicolaische Verlagsbuchhandlung, Berlin, Germany 1863.

42. I. B. Sollas, Q. J. Microsc. Sci. 1907, 51, 115.

43. E. Jones, R. McCance, L. Shackleton, J. Exp. Biol. 1935, 12, 59.

44. S. Tillier, J.-P. Cuif, Comptes Rendus Académie Sci. Sér. 2 Mécanique Phys. Chim. Sci. Univers. Sci. Terre 1986, $303,627$.

45. R. Cruz, U. Lins, M. Farina, Biol. Bull. 1998, 194, 224.

46. D. Faivre, T. Ukmar-Godec, Angew. Chem. Int. Ed. Engl. 2015, 54, 4728.

47. K. M. Towe, H. A. Lowenstam, J. Ultrastruct. Res. 1967, $17,1$.

48. L. A. Evans, D. J. Macey, J. Webb, Mar. Biol. 1991, 109, 281.

49. D. J. Macey, L. R. Brooker, J. Morphol. 1996, 230, 33.

50. A. P. Lee, J. Webb, D. J. Macey, W. van Bronswijk, A. R. Savarese, G. C. de Witt, J. Biol. Inorg. Chem. 1998, 3, 614.

51. L. R. Brooker, D. J. Macey, Am. Malacol. Bull. 2001, 16, 203.

52. A. P. Lee, L. R. Brooker, D. J. Macey, J. Webb, W. van Bronswijk, J. Biol. Inorg. Chem. 2003, 8, 256.

53. J. A. Shaw, D. J. Macey, L. R. Brooker, E. J. Stockdale, M. Saunders, P. L. Clode, J. Morphol. 2009, $270,588$.

54. L. Gordon, D. Joester, Nature 2011, 469, 194.

55. S. Emmanuel, J. A. Schuessler, J. Vinther, A. Matthews, F. von Blanckenburg, Biogeosciences 2014, 11, 5493.

56. J. A. Shaw, D. J. Macey, L. R. Brooker, J. Mar. Biolog. Assoc. U.K. 2008, 88, 597.

57. L. R. Brooker, A. P. Lee, D. J. Macey, W. van Bronswijk, J. Webb, Mar. Biol. 2003, 142, 447.

58. A. P. Lee, L. R. Brooker, D. J. Macey, W. van Bronswijk, J. Webb, Calcif. Tissue Int. 2000, 67, 408.

59. L. R. Brooker, A. P. Lee, D. J. Macey, J. Webb, W. van Bronswijk, Venus 2006, 65, 71.

60. P. van der Wal, in Iron biominerals (Eds: R. B. Frankel, R. P. Blakemore), Plenum Press, New York, USA 1990, Ch. 2.

61. M. Saunders, C. Kong, J. A. Shaw, P. L. Clode, Microsc. Microanal. 2011, 17, 220.

62. H. A. Lowenstam, Chem. Geol. 1972, 9, 153.

63. D. J. Macey, J. Webb, L. R. Brooker, Bull. Inst. Océanogr. (Monaco) 1994, 4, 191.

64. H. A. Lowenstam, S. Weiner, Science 1985, 227, 51.

65. H. A. Lowenstam, S. Weiner, in On biomineralization (Eds: H. A. Lowenstam, S. Weiner), Oxford University Press, Oxford 1989, Ch. 6.

Page $12 / 17$ 
66. L. A. Evans, R. Alvarez, J. Biol. Inorg. Chem. 1999, 4, 166.

67. L. A. Evans, D. J. Macey, J. Webb, Calcif. Tissue Int. 1992, 51, 78.

68. K. S. Kim, J. Webb, D. J. Macey, D. D. Cohen, J. Inorg. Biochem. 1986, $28,337$.

69. N. W. Runham, Q. J. Microsc. Sci. 1961, 102, 371.

70. N. W. Runham, P. R. Thronton, D. A. Shaw, R. C. Wayte, Z. Zellforsch. 1969, 99, 608.

71. G. Grime, F. Watt, S. Mann, C. Perry, J. Webb, R. Williams, Trends Biochem. Sci. 1985, 10, 6.

72. T. G. St Pierre, S. Mann, J. Webb, D. P. E. Dickson, N. W. Runham, R. J. P. Williams, Proc. R. Soc. B. 1986, $228,31$.

73. S. Mann, C. C. Perry, J. Webb, B. Luke, R. J. P. Williams, Proc. R. Soc. B 1986, 227, 179.

74. P. van der Wal, J. Ultrastruct. Mol. Struct. Res. 1989, 102, 147.

75. C. Huang, C.-W. Li, M. Deng, T. Chin, IEEE Trans. Magn. 1992, 28, 2409.

76. B. Rinkevich, Mar. Biol. 1993, 117, 269.

77. K. J. Liddiard, J. G. Hockridge, D. J. Macey, J. Webb, W. van Bronswijk, Molluscan Res. 2004, 24, 21.

78. R. Cruz, M. Farina, Mar. Biol. 2005, 147, 163.

79. M. S. Davies, D. J. Proudlock, A. Mistry, Ecotoxicology 2005, 14, 465.

80. E. D. Sone, S. Weiner, L. Addadi, J. Struct. Biol. 2007, 158, 428.

81. T.-E. Hua, C.-W. Li, Zool. Stud. 2007, 46, 379.

82. W. Krings, T. Faust, A. Kovalev, M.T. Neiber, M. Glaubrecht, S. N. Gorb, R. Soc. Open Sci. 2019, 6, 2054.

83. A. Mikovari, J. Williams, F. Oakes, R. B. Lincium, A. J. Zellmer, G. G. Martin, J. Shellfish Res. 2015, 34, 893.

84. T. Ukmar-Godec, G. Kapun, P. Zaslansky, D. Faivre, J. Struct. Biol. 2015, 192, 392.

85. D. J. Macey, L. R. Brooker, V. Cameron, Molluscan Res. 1997, 18, 33.

86. V. O. Barkalova, A. E. Fedosov, Y. I. Kantor, Molluscan Res. 2016, 36, 54.

87. G. Ponte, M. V. Modica, Front. Physiol. 2017, 8, 580.

88. G. Haszprunar, J. Molluscan Stud. 1988, 54, 367.

89. T. Sasaki, Univ. of Tokyo Bull. 1998, 38, 1.

90. L. R. L. Simone, Arq. Zool. 2011, 42, 161.

91. C. A. Meirelles, H. Matthews-Cascon, Thalassas 2003, 19, 45.

92. A. J. Peile, J. Conchol. 1937, 20, 292.

93. E. Marcus, E. Marcus, Abhandlungen der Mathematisch-Naturwissenschaftlichen Klasse. Akademie der Wissenshaften und der Literatur in Mainz 1963, 1 , 1.

94. D. G. Reid, The littorinid molluscs of mangrove forests in the Indo-Pacific region: The genus Littoraria, British Museum Natural History, London 1986. 95. D. G. Reid, Philos. Trans. R. Soc. Lond. B 1989, 324, 1.

96. D. G. Reid, Y.-M. Mak, J. Molluscan Stud. 1999, 65, 355.

97. V. Fretter, A. Graham, British prosobranch molluscs, The Ray Society, London 1994.

98. J. P. Cabral, Web Ecol. 2007, 7, 11.

99. M. H. Nesson, Thesis, California Institute of Technology 1969.

100. J. A. Shaw, L. R. Brooker, D. J. Macey, Molluscan Res. 2002, 22, 93.

101. K. Isarankura, N. Runham, Malacologia 1968, 7, 71.

102. D. K. Padilla, D. E. Dittman, J. Franz, R. Sladek, J. Molluscan Stud. 1996, 62, 275.

103. N. W. Runham, Nature 1962, 194, 992.

104. U. Mackenstedt, K. Märkel, Zoomorphology 1987, 107, 209.

105. B. Mischor, K. Märkel, Zoomorphology 1984, 104, 42.

106. Y. Fujioka, J. Exp. Mar. Biol. Ecol. 1985, 90, 43.

107. Z. Liu, M. A. Meyers, Z. Zhang, R. O. Ritchie, Progr. Mater. Sci. 2017, 88, 467.

108. J. F. V. Vincent, J. Molluscan Stud. 1980, 46, 129.

109. L. A. Evans, D. J. Macey, J. Webb, Philos. Trans. R. Soc. Lond. B 1990, 329, 87.

110. L. A. Evans, D. J. Macey, J. Webb, Acta Zool. 1994, 75, 75.

111. R. J. Wealthall, L. R. Brooker, D. J. Macey, B. J. Griffin, J. Morphol. 2005, 265, 165.

112. W. Krings, A. Kovalev, S. N. Gorb, Proc. Royal Soc. B 2021, 288, 20203173.

113. W. Krings, A. Kovalev, S. N. Gorb, Acta Biomater. 2021, 135, 458.

114. G. E. Radwin, H. W. Wells, Bull. Mar. Sci. 1968, 18, 72.

115. D. Grünbaum, D. K. Padilla, Integr. Comp. Biol. 2014, 54, 323.

116. C. Scheel, S. N. Gorb, M. Glaubrecht, W. Krings, Biol. Open 2020, 9, bio055699. 
117. J. Gray, Ann. Mag. Nat. Hist. 1853, 11, 124.

118. L. H. Hyman, Mollusca I. Aplacophora, polyplacophora, monoplacophora. Gastropoda, the coelomate bilateria. The invertebrates 6, McGraw-Hill Book Company, New York 1967.

119. M. Nixon, J. Zool. 1995, 236, 73.

120. G. Haszprunar, K. J. Götting, in Spezielle Zoologie. Teil 1: Einzeller und wirbellose Tiere (Eds: W. Westheide, R. Rieger), Springer, Berlin, Germany 2007.

121. H. A. Lowenstam, Geol. Soc. Am. Bull. 1962, 73, 435.

122. J. L. Kirschvink, H. A. Lowenstam, EPSL 1979, 44, 193.

123. Y. Han, C. Liu, D. Zhou, F. Li, Y. Wang, X. Han, Bioelectromagnetics 2011, 32, 226.

124. M. Nemoto, D. Ren, S. Herrera, S. Pan, T. Tamura, K. Inagaki, D. Kisailus, Sci. Rep. 2019, 9, 856.

125. J. M. McCoey, M. Matsuoka, R. W. de Gille, L. T. Hall, J. A. Shaw, J.-P. Tetienne, D. Kisailus, L. C. L. Hollenberg, D. A. Simpson, Small Methods 2020, 4, 1900754.

126. H. A. Lowenstam, Science 1967, 56, 1373.

127. L. R. Brooker, A. P. Lee, D. J. Macey, J. Webb, in Encyclopedia of materials: Science and technology (Eds: K. H. J. Buschow, R. W. Cahn, M. C. Flemings, B. Ilschner, E. J. Kramer, S. Mahajan, P. Veyssière), Elsevier Science Ltd., Oxford 2001.

128. J. A. Shaw, D. J. Macey, L. R. Brooker, E. J. Stockdale, M. Saunders, P. L. Clode, Microsc. Microanal. 2009, 15, 154.

129. T. E. Creighton, Biol. Chem. 1997, 378, 731.

130. M. M. Harding, Acta Cryst. D 2002, 58, 872.

131. T. Hayes, Pac. Sci. 1983, 37, 27.

132. D. K. Padilla, J. Exp. Mar. Biol. Ecol. 1984, 79, 105.

133. D. H. Kesler, E. H. Jokinen, W.R. Jr. Munns, Can. J. Zool. 1986, 64, 2570.

134. W. Blinn, R. E. Truitt, A. Pickart, J. N. Am. Benthol. Soc. 1989, 8, 237.

135. S. J. Hawkins, D. C. Watson, A. S. Hill, S. P. Harding, M. A. Kyriakides, S. Hutchinson, T. A. Norton, J. Molluscan Stud. $1989,55,151$.

136. C. J. Franz, J. Molluscan Stud. 1990, 56, 25.

137. R. C. Thompson, L. E. Johnson, S. J. Hawkins, J. Exp. Mar. Biol. Ecol. 1997, 218, 63.

138. K. Iken, J. Exp. Mar. Biol. Ecol. 1999, 236, 133.

139. R. E. Forrest, M. G. Chapman, A. J. Underwood, J. Exp. Mar. Biol. Ecol. 2001, 258, 155.

140. V. K. Dimitriadis, in The biology of terrestrial molluscs (Ed: G. M. Barker), CABI Publishing, Oxon, United Kingdom 2001, Ch. 5.

141. B. Speiser, in The biology of terrestrial molluscs (Ed: G. M. Barker), CABI Publishing, Oxon, United Kingdom 2001, Ch. 6.

142. T. Sitnikova, S. I. Kiyashko, N. Maximova, G. V. Pomazkina, P. Roepstorf, E. Wada, E. Michel, Hydrobiologia 2012, $682,75$.

143. F. S. Bergmeier, L. Ostermair, K. M. Jörger, Curr. Biol. 2021, 31, R836.

144. J. A. Goodheart, A. L. Bazinet, Á. Valdés, A. G. Collins, M. P. Cummings, BMC Evol. Biol. 2017, 17, 221.

145. D. K. Padilla, Mar. Biol. 1985, 90, 103.

146. D. K. Padilla, Ecology 1989, 70, 835.

147. A. B. Wilson, M. Glaubrecht, A. Meyer, Proc. R. Soc. B 2004, 271, 529.

148. W. Ponder, D. R. Lindberg, Phylogeny and evolution of the Mollusca, University of California Press, Berkeley, California 2008.

149. K. M. Jörger, I. Stöger, Y. Kano, H. Fukuda, T. Knebelsberger, M. Schrödl, BMC Evol. Biol. 2010, 10, 323.

150. K. Kocot, J. Cannon, C. Todt, M. R. Citarella, A. B. Kohn, A. Meyer, S. R. Santos, C. Schander, L. L. Moroz, B. Lieb, K. M. Halanych, Nature $2011,477,452$.

151. K. M. Kocot, A. J. Poustka, I. Stöger, K. M. Halanych, M. Schrödl, Sci. Rep. 2020, 10, 101.

152. S. Smith, N. Wilson, F. Goetz, C. Feehery, S. C. S. Andrade, G. W. Rouse, G. Giribet, C. W. Dunn, Nature 2011, 480, 364.

153. G. Haszprunar, A. Wanninger, Curr. Biol. 2012, 22, R510.

154. A. Wanninger, T. Wollesen, Biol. Rev. 2019, 94, 102.

155. I. Irisarri, J. E. Uribe, D. J. Eernisse, R. Zardoya, BMC Evol. Biol. 2020, 20, 22.

156. I. F. Smith, (Preprint) doi:10.13140/RG.2.2.28288.58889, submitted: 2020.

157. I. F. Smith, (Preprint) doi:10.13140/RG.2.2.10640.64005, submitted: 2020.

158. A. Quetglas, A. de Mesa, F. Ordines, A. Grau, Deep Res. Part I Oceanogr. Res. Pap. 2010, 57, 999.

159. M. Coelho, P. Domingues, E. Balguerias, M. Fernandez, J. P. Andrade, Fish. Res. 1997, 29, 245.

160. G. M. Notman, R. A. McGill, S. J. Hawkins, M. T. Burrows, Mar. Ecol. Prog. Ser. 2016, 549, 113.

161. V. Marchais, A. Jolivet, S. Hervé, S. Roussel, B. R. Schöne, J. Grall, L. Chauvaud, J. Clavieret, Mar. Biol. 2017, $164,71$.

162. T. E. Eichhorst, Neritidae of the World: Volume 1 and 2, ConchBooks, 2016.

163. M. J. R. Bourguignat, Notice prodromique sur les mollusques terrestres et fluviatiles, Savy, Paris 1885.

164. M. J. R. Bourguignat, Iconographie malacologiques des animaux mollusques fluviatiles du Lac Tanganika, Corbeil, Crété 1888. 
165. K. West, E. Michel, J. Todd, D. Brown, J. Clabaugh, The gastropods of Lake Tanganyika: Diagnostic key, classification and notes on the fauna, Special publications: Societas Internationalis Limnologiae - Int. Assoc. of Theoretical and Applied Limnology, 2003.

166. M. Glaubrecht, Zoosystematics Evol. 2008, 84, 71.

167. J. E. S. Moore, The Tanganyika problem, Burst and Blackett, London 1903.

168. E. Leloup, Exploration hydrobiologique du Lac Tanganika (1946-1947), Bruxelles 1953.

169. D. Brown, Freshwater snails of Africa and their medical importance, Taylor and Francis, London 1994.

170. L. Germain, Bull. Mus. Natl. Hist. Nat. 1908, 14, 1.

171. G. W. Coulter, Lake Tanganyika and its life, Oxford University Press, Oxford 1991.

172. K. Bandel, Zbl. Geol. Paläont. 1997, 1, 233.

173. H. A. Pilsbry, J. Bequaert, Bull. Am. Mus. Nat. Hist. 1927, 53, 69.

174. Alvin F. S. L. Lok, W. F. Ang, P. X. Ng, B. Y. Q. Ng, S. K. Tan, NiS 2011, 4, 115.

175. R. R. Das, J. J. Jeevamani, R. Sankar, D. S. Kumar, P. Krishnan, P. Ramachandran, R. Ramachandran, IJMS 2018, $47,2002$.

176. D. C. Watson, T. A. Norton, J. Exp. Mar. Biol. Ecol. 1985, 88, 193.

177. D. W. Imrie, C. R. McCrohan, S. J. Hawkins, Hydrobiologia 1990, 193, 191.

178. M. Olsson, L. Svärdh, G. B. Toth, Mar. Ecol. Prog. Ser. 2007, 348, 221.

179. J. S. Lauzon-Guay, R. E. Scheibling, J. Shellfish Res. 2009, 28, 581.

180. A. E. Bogan, E. H. Hanneman, Ellipsaria 2013, 15, 18.

181. E. E. Strong, L. A. Galindo, Y. I. Kantor, PeerJ 2017, 11, e3638.

182. J. H. Himmelman, J. R. Hamel, Mar. Biol. 1993, 116, 423.

183. H. Barnes, H. T. Powell, J. Anim. Ecol. 1954, 23, 361.

184. V. L. Waters, Veliger 1973, 15, 174.

185. M. Edmunds, G. Potts, R. Swinfen, V. Waters, J. Mar. Biol. Assoc. U. K. 1974, 54, 939.

186. M. Edmunds, J. Molluscan Stud. 1983, 49, 80.

187. C. G. Sørensen, C. Rauch, M. Pola, M. A. E. Malaquias, J. Mar. Biol. Assoc. U. K. 2020, 100, 733.

188. J. E. Forrest, Proc. Linn. Soc. Lond. 1953, 164, 225.

189. R. M. Rose, J. Zool. 1971, 165, 317.

190. W. Krings, H. Karabacak, S. N. Gorb, J. R. Soc. Interface 2121, 18, 20210377.

191. W. Krings, J. Marcé-Nogué, H. Karabacak, M. Glaubrecht, S. N. Gorb, Acta Biomater. 2020, 115, 317.

192. W. Krings, S. N. Gorb, J. Molluscan Stud. 2021, 87, eyab007.

193. A. P. Lee, L. R. Brooker, W. van Bronswijk, D. J. Macey, J. Webb, Biopolymers 2003, 72, 299.

\section{Figures}




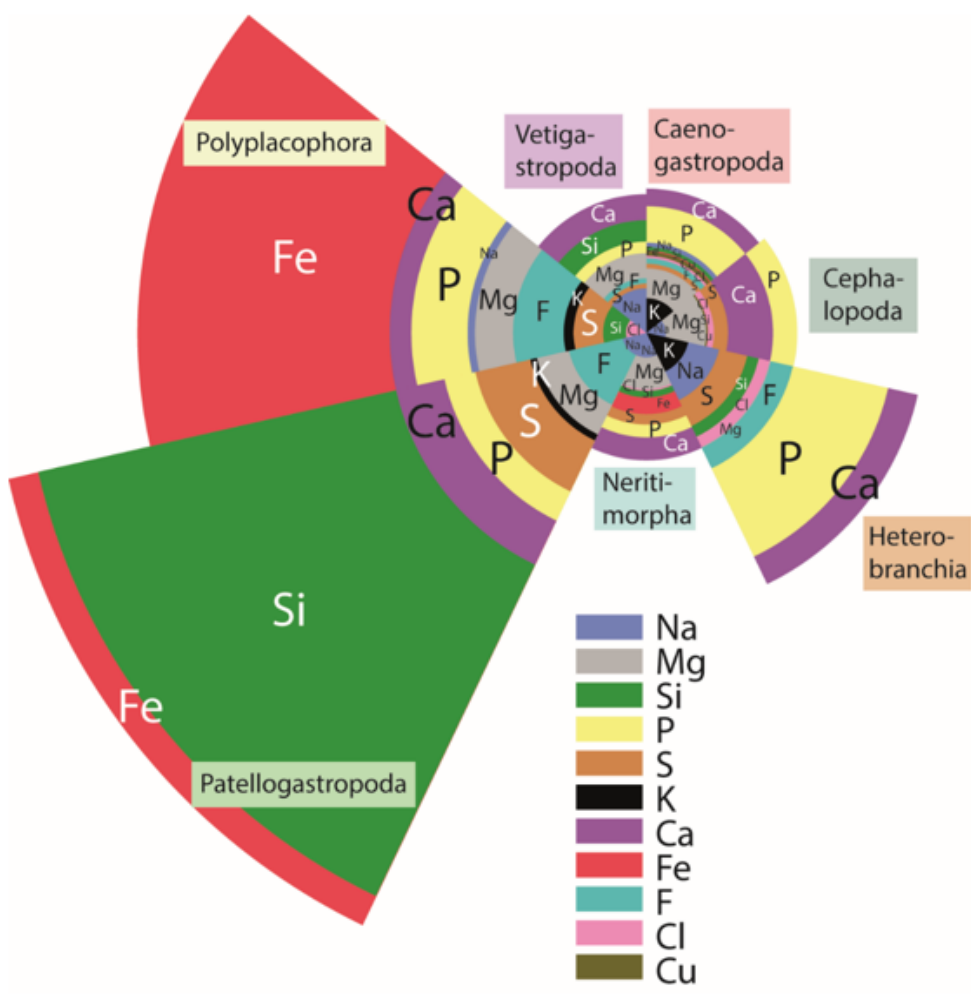

Figure 1

Elemental proportions of the species' radular teeth, summarized for taxa (Patellogastropoda, Polyplacophora, Vetigastropoda, Caenogastropoda, Cephalopoda, Heterobranchia, Neritimorpha) to ease comparison in the radular mineral content.

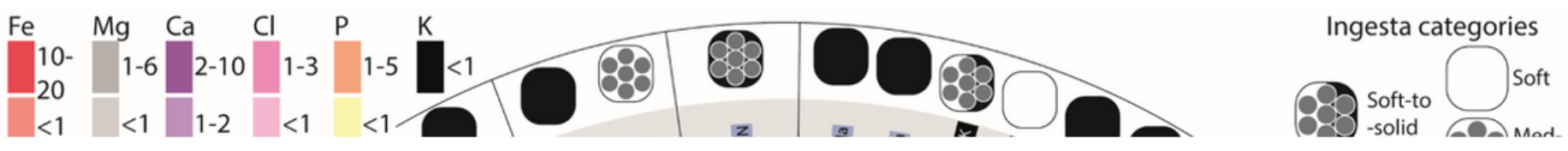


Elements detected, in mean atomic percent (represented by different colors), and assigned ingesta category (soft, medium, solid, soft to solid, medium to solid) for each species, sorted to the major molluscan groups (Polyplacophora, Cephalopoda, Gastropoda: Patellogastropoda, Vetigastropoda,

Caenogastropoda, Neritimorpha, Heterobranchia). Elements are sorted to the defined composition-types (I, II, III, IV, V, OB).

\section{Supplementary Files}

This is a list of supplementary files associated with this preprint. Click to download.

- PeriodictableSupplements.pdf 